\title{
SEDIMENTOLOGY
}

the joumal of the

IntemationalAssoclation of Sedimentologists

\section{Mineralogy and geochemistry of atypical reduction spheroids from the Tumblagooda Sandstone, Western Australia}

\begin{tabular}{|c|c|}
\hline Journal: & Sedimentology \\
\hline Manuscript ID & SED-2019-OM-038.R1 \\
\hline Manuscript Type: & Original Manuscript \\
\hline $\begin{array}{l}\text { Date Submitted by the } \\
\text { Author: }\end{array}$ & 08-Jul-2019 \\
\hline Complete List of Authors: & $\begin{array}{l}\text { Fox, David; Commonwealth Scientific and Industrial Research } \\
\text { Organisation, Mineral Resources; Curtin University, School of Earth and } \\
\text { Planetary Sciences } \\
\text { Spinks, Sam; Commonwealth Scientific and Industrial Research } \\
\text { Organisation, Mineral Resources } \\
\text { Thorne, Robert; Commonwealth Scientific and Industrial Research } \\
\text { Organisation, Mineral Resources } \\
\text { Barham, Milo; Curtin University, Department of Applied Geology } \\
\text { Aspandiar, Mehrooz; Curtin University, School of Earth and Planetary } \\
\text { Sciences } \\
\text { Armstrong, Joseph; University of Aberdeen, Geology and Petroleum } \\
\text { Geology; Commonwealth Scientific and Industrial Research Organisation, } \\
\text { Mineral Resources } \\
\text { Uysal, Tonguc; Commonwealth Scientific and Industrial Research } \\
\text { Organisation, Energy } \\
\text { Timms, Nick; Curtin University, Department of Applied Geology } \\
\text { Pearce, Mark; Commonwealth Scientific and Industrial Research } \\
\text { Organisation, Mineral Resources } \\
\text { Verrall, Michael; Commonwealth Scientific and Industrial Research } \\
\text { Organisation, Mineral Resources } \\
\text { Godel, Belinda; Commonwealth Scientific and Industrial Research } \\
\text { Organisation, Mineral Resources } \\
\text { Whisson, Brad; LabWest Minerals Analysis Pty Ltd }\end{array}$ \\
\hline Keywords: & $\begin{array}{l}\text { Red beds, Diagenesis, Redox, Carnarvon Basin, Metal-reducing bacteria, } \\
\text { Haematite, Perth Basin, Svanbergite }\end{array}$ \\
\hline \multicolumn{2}{|c|}{$\begin{array}{l}\text { Note: The following files were submitted by the author for peer review, but cannot be converted to PDF. } \\
\text { You must view these files (e.g. movies) online. }\end{array}$} \\
\hline \multicolumn{2}{|c|}{$\begin{array}{l}\text { KAL17_1 XRD.svg } \\
\text { KAL17_29 XRD.svg } \\
\text { 4_SHARP_0017_simple_volume_rendering.mpg } \\
\text { 37_SHARP_0018_3D_movie1.mpg }\end{array}$} \\
\hline
\end{tabular}


1 Mineralogy and geochemistry of atypical 2 reduction spheroids from the Tumblagooda 3 Sandstone, Western Australia

6 David C. M. Fox ${ }^{1,2}$, Samuel C. Spinks ${ }^{1}$, Robert L. Thorne ${ }^{1}$, Milo Barham²,3, Mehrooz

7 Aspandiar ${ }^{2}$, Joseph G. T. Armstrong ${ }^{1,4}$, Tonguç Uysal ${ }^{5}$, Nicholas E. Timms², Mark A. 8 Pearce $^{1}$, Michael Verrall ${ }^{1}$, Belinda Godel ${ }^{1}$, Brad Whisson $^{6}$

${ }^{1}$ CSIRO Mineral Resources, 26 Dick Perry Avenue, Kensington, WA 6151, Australia

${ }^{2}$ The Institute for Geoscience Research (TIGeR), School of Earth and Planetary

Sciences, Curtin University, GPO Box U1987, Perth, WA 6845, Australia

${ }^{3}$ Centre for Exploration Targeting, Curtin Node, School of Earth and Planetary

Sciences, Curtin University, GPO Box U1987, Perth, WA 6845, Australia

${ }^{4}$ School of Geosciences, University of Aberdeen, Aberdeen AB24 3UE, UK

${ }^{5}$ CSIRO Energy, 26 Dick Perry Avenue, Kensington, WA 6151, Australia

Corresponding author: 


\section{Abstract}

Reduction spheroids are small-scale, biogenic, redox-controlled, metal enrichments that occur within red beds globally. This study provides the first analysis of the compositionally unique reduction spheroids of the Tumblagooda Sandstone. The work aims to account for their composition and consequently improve existing models for reduction spheroids generally, which presently fail to account for the mineralogy of the Tumblagooda Sandstone reduction spheroids. Interstitial areas between detrital grains contained in the cores of these reduction spheroids are dominated by microplaty haematite, in addition to minor amounts of svanbergite, gorceixite, anatase, uraninite, monazite, and illite. The haematite-rich composition, along with an absence of base metal phases and the vanadiferous mica roscoelite, makes these reduction spheroids notable in comparison to other global reduction spheroid occurrences. Analyses of illite crystallinity provide values for samples of the Tumblagooda Sandstone host rock corresponding to heating temperatures of $\sim 200^{\circ} \mathrm{C}$. Consequently, while Tumblagooda Sandstone reduction spheroids formed via the typical metabolic processes of dissimilatory metal-reducing bacteria, the combination of a unique mineralogy and illite crystallinity analysis provides evidence of more complex late-stage heating and reoxidation. This has not previously been recognised in other reduction spheroids and therefore expands the existing model for reduction spheroid genesis by also considering the potential for late-stage alteration. As such, future reduction spheroid studies should consider the potential impact of post-formation modification, particularly where they are to be used as evidence of ancient microbial processes; such as in the search for early evidence of life in the geological record on Earth or other planets. Additionally, because of their potential for modification, reduction spheroids serve as a record of the redox 
45 history of red beds and their study could provide insights into the evolution of redox

46 conditions within a given red bed during its diagenesis. Finally, this paper also provides

47 insights into the relatively understudied diagenetic history of the Tumblagooda

48 Sandstone; supplying the first reliable and narrow constraints on its thermal history.

49 This has important implications for the thermal history of the Carnarvon Basin and its

50 petroleum prospectivity more broadly. 


\section{Introduction}

Reduction spheroids are small-scale $(<30 \mathrm{~cm})$ metalliferous spheroidal features that occur in red terrestrial sedimentary rocks (red beds) and are defined by the presence of a dark mineralised core, with a surrounding pale haematite dissolution halo (Fig. 1). Interest in reduction spheroids primarily relates to their strong enrichment in redoxsensitive elements, including U, V, Au, Cu and Ag, among others (Hofmann, 1990a; Parnell et al., 2015a; Parnell et al., 2015b). Consequently, it has been proposed that reduction spheroids could be useful in (i) further understanding processes associated with low-temperature redox-controlled metal concentration in sedimentary rocks, such as in unconformity-related U deposits (Hofmann, 1999), and (ii) as a potential tool in exploration for regional metal anomalies (Parnell, 2017). The metabolic processes of dissimilatory metal-reducing bacteria (DMRB) consuming organic matter in the sediment are believed to be critical in the formation of reduction spheroids. Organic matter is used by these bacteria as an energy source and reductant to allow for the bacterially-mediated reductive precipitation of dissolved metals into the cores of reduction spheroids (Spinks et al., 2010; Spinks et al., 2014; Parnell et al., 2016). As such, reduction spheroids are believed to also be of use as a potential biomarker for recording the early colonisation of the terrestrial biosphere by metal-reducing bacteria and in the search for life in the Martian geological record (Spinks et al., 2010; Thompson et al., 2014; Parnell et al., 2015a; Spinks et al., in review).

Here, we investigate the reduction spheroids of the Tumblagooda Sandstone; an Ordovician-Silurian red bed that occurs through the base of the Southern Carnarvon Basin, cropping out in the area immediately surrounding the Kalbarri townsite in Western Australia (Hocking, 2000). It is notable that reduction spheroids at these 
localities are exceptionally abundant and compositionally unique relative to other red beds. Despite this, the reduction spheroids of the Tumblagooda Sandstone are completely unstudied. The aim of this paper is to provide the first study of the Tumblagooda Sandstone reduction spheroids in order to account for their unique mineralogy and, consequently, improve existing models for reduction spheroids generally as the existing models for reduction spheroid genesis do not adequately account for the mineralogy of the Tumblagooda Sandstone reduction spheroids. This holds key implications for understanding the processes that produce reduction spheroids broadly and is a particularly important consideration for future studies where reduction spheroids may be recognised as biomarkers of ancient DMRB in the early terrestrial biosphere on Earth and potentially Mars (Spinks et al., 2010; Thompson et al., 2014).

\section{Geological Background}

The Tumblagooda Sandstone (Kettanah et al., 2015) is an Ordovician-lower Silurian red bed that extends throughout most of the basal Southern Carnarvon Basin and portions of the northern Perth Basin of Western Australia (Fig. 2/3a) (Hocking, 1991). This formation is most prominent near Kalbarri, Western Australia and best exposed at its type section in the Murchison River gorge and along the coastal cliffs south of Kalbarri, $600 \mathrm{~km}$ north of Perth (Fig. 3) (Hocking, 1991). The Tumblagooda Sandstone is inferred to be over $2000 \mathrm{~m}$ thick where it occurs through the Carnarvon Basin (Kettanah et al., 2015), and is observed to be $1210 \mathrm{~m}$ thick at its type section through the Murchison River Gorge (Hocking, 1991). The Silurian carbonate-rich Dirk Hartog Group is interpreted to conformably overlie the Tumblagooda Sandstone and provides conodont biostratigraphic age constraints (Iasky and Mory, 1999). The Tumblagooda Sandstone is of global palaeontological significance for its diverse and 
well preserved ichnofossils, which provide early evidence of a thriving ecosystem of terrestrial arthropods during the Silurian (Trewin and McNamara, 1995).

As the basal unit within the Southern Carnarvon Basin, the Tumblagooda Sandstone represents the earliest widespread sediment deposition following the initial formation of the Southern Carnarvon Basin in an epicratonic rift setting during the Late Ordovician (Hocking, 1991; Mory et al., 2003). The sediment source for the Tumblagooda Sandstone is poorly constrained, with provenance indicators historically providing ambiguous results. Reflecting this, the Yilgarn Craton, Albany-Fraser Orogen, Pinjarra Orogen, Capricorn Orogen, North Indian Orogen, East Africa, and Antarctica have all previously been proposed as potential sources based upon various analytical techniques. These techniques include detrital zircon $\mathrm{U} / \mathrm{Pb}$ geochronology, analysis of heavy mineral assemblages, and petrographic analysis of textural and mineralogical characteristics of different portion of the Tumblagooda Sandstone (Hocking, 1991; Mory et al., 2003; Kettanah et al., 2015; Markwitz et al., 2017).

The Gascoyne Platform of the Southern Carnarvon Basin (Fig. 2) hosts the Tumblagooda Sandstone and is dominated by Ordovician to Devonian strata, with a thin cover of Cretaceous to Cenozoic sediments (Ghori, 1999). The deposition of the Tumblagooda Sandstone was followed by the Dirk Hartog Group carbonates and evaporites through the Late Ordovician and Silurian in a shallow-marine environment (Hocking et al., 1987; Hocking, 1991; Ghori, 1999). The deposition of the Dirk Hartog Formation was followed by deposition of carbonate and siliciclastic sediments following a short pause in deposition during the Early Devonian (Ghori, 1999; Mory et al., 2003). After an extended period of non-deposition until the Middle Devonian, a marine transgression was associated with the deposition of thick shallow marine to 
123 transitional strata throughout the Southern Carnarvon Basin during the Middle to Late

124 Devonian (Hocking et al., 1987; Ghori, 1999; Iasky et al., 2003; Mory et al., 2003). This

125 was followed by a significant depositional hiatus throughout most of the Gascoyne

126 Platform until the Early Cretaceous, as the Gascoyne Platform was a positive

127 topographic feature during this time (Iasky et al., 2003). This is proposed to be a

128 consequence of uplift during the Middle Carboniferous due to the collision of

129 Gondwana and Laurasia, rifting through the Middle Carboniferous to Permian

130 activating several fault systems that diverted sediment to other depocentres, and non-

131 deposition or erosion due to the rifting of India from Australia beginning in the Middle

132 Jurassic (Iasky and Mory, 1999; Mory et al., 2003). The uppermost portion of the

133 Southern Carnarvon Basin is dominated by Cretaceous to Cenozoic marine carbonates

134 as a result of a widespread transgression during this period (Iasky and Mory, 1999;

135 Mory et al., 2003).

136 Foundational work by Hocking (1991) recognised five stratigraphic facies associations

137 (FA), designated FA1-FA5, reflecting broad-scale sedimentological variations within

138 the Tumblagooda Sandstone. These facies associations and their stratigraphic

139 relationships are summarised in Fig. 4 with the occurrence of reduction spheroids noted

140 within the sequence. However, FA5 is not included due to its common omission from

141 the literature, as discussed at the end of this section. This informal scheme has been

142 adopted in subsequent works as the standard sub-divisions of the Tumblagooda

143 Sandstone (Trewin and McNamara, 1995; Mory and Hocking, 2008).

144 FA1 is a red and white dominantly sandy, $\sim 440 \mathrm{~m}$ thick sequence at the base of the

145 Tumblagooda Sandstone that is largely devoid of bioturbation and interpreted to have

146 been deposited in a large braided fluvial system (Hocking, 1991). The overlying FA2 is 
$147200 \mathrm{~m}$ thick at the type section and is similarly dominated by red and white sandstone,

148 though it is significantly more bioturbated (Hocking, 1991). This bioturbation has been

149 referred to by Trewin (1993a) as the 'Heimdallia-Diplichnites Ichnofauna'. Reduction

150 spheroids were observed at the base of FA2, but were not logged in detail, as the coastal

151 sections of the Tumblagooda Sandstone were the focus of this study. Hocking (1991;

$1522000 ; 2006$ ) has consistently argued that FA2 was deposited within an intertidal

153 environment. However, Trewin (1993b) and later, McNamara (2014), have suggested

154 that FA2 was deposited in a mix of terrestrial fluvial and aeolian depositional

155 environments. FA2 is sharply overlain by FA3, which is up to $260 \mathrm{~m}$ in thickness at the

156 type section and is defined by a generally coarse-grained, poorly sorted, trough cross-

157 bedded red sandstone that is observed to host abundant reduction spheroids (Hocking,

158 1991; Trewin and McNamara, 1995). The 'Gabba-Gabba Member', a laterally extensive

159 pebbly marker bed, up to 1.2 m thick, occurs near the top of FA3 (Hocking, 1991). The

160 occurrence of this bed also marks a significant increase in bioturbation, characterised as

161 the 'Skolithos-Diplocraterion Ichnofauna' (Trewin and McNamara, 1995). FA3 is up to

$162260 \mathrm{~m}$ at the type section and is generally interpreted to have been deposited in a high-

163 energy braided-fluvial environment (Hocking, 1991; Trewin, 1993a; Trewin and

164 McNamara, 1995; Hocking, 2000). The prevalence of bioturbation toward the top

165 represents an increasing marine influence (Trewin and McNamara, 1995). FA3 can be

166 observed to grade upwards into FA4 by the increasing presence of clay-rich beds of red

167 siltstone (Hocking, 1991). With this considered, FA4 is exposed over up to $45 \mathrm{~m}$ at the

168 type section and is generally defined by the presence of red oxidised and white reduced

169 sandy siltstones and very fine to medium-grained sandstones, which may be intensely

170 bioturbated by the 'Skolithos-Diplocraterion Ichnofauna' (Hocking, 1991; Trewin, 
171 1993a). These finer-grained lithologies are interpreted to indicate deposition in a lower

172 energy deltaic environment, proximal to the fluvial environment of FA3 (Hocking,

173 2000). However, the abundant marine ichnofossils within FA4 could be accounted for

174 by the reworking of wave-generated sandbars within a prograding fluvial system

175 (Trewin, 1993a; Trewin and McNamara, 1995). Much like the underlying FA3, FA4 is

176 also observed to contain reduction spheroids (Fig. 4); occurring densely through certain

177 horizons. FA5 is isolated from the other facies associations, occurring to the east of the

178 nearby Northampton Complex (Fig. 2/3a); a Proterozoic gneissic basement inlier of the

179 Pinjarra Orogen (Fitzsimons, 2001). As such, FA5's stratigraphic relationship to the rest

180 of the Tumblagooda Sandstone is unknown and it is commonly omitted from the

181 literature (Trewin, 1993b; Trewin, 1993a; Trewin and McNamara, 1995; Trewin and

182 Fallick, 2000; Kettanah et al., 2015). As a result of this and FA5's geographic isolation,

183 it was not analysed in this study. Nonetheless, FA5 is dominated by coarse-grained red

184 sandstones and conglomerates, and on this basis is interpreted to have been deposited in

185 either a high-energy fluvial or alluvial system (Hocking, 1991). Broadly the climate at

186 the time of deposition of this sequence (FA1-5) has been interpreted to be arid; as is

187 characteristic of red beds generally (Walker, 1967).

\section{Methods}

\section{Sample Collection and Preparation}

190 Sampling of reduction spheroids for this study was undertaken through the sequence

191 exposed at Red Bluff, Rainbow Valley, and Mushroom Rock (Fig. 3b/c). These

192 localities correspond to FA3/FA4 and FA4, respectively (Hocking, 1991). As Red Bluff

193 and Rainbow Valley provide excellent examples of FA3 and FA4, in this study FA3

194 will be herein informally referred to as the Red Bluff unit (RBU) and FA4 will be 
195 referred to as the Rainbow Valley unit (RVU). Sampling at these localities was of in-situ

196 reduction spheroids from several horizons within a sequence $\sim 40 \mathrm{~m}$ thick over a strike

197 length of $\sim 2 \mathrm{~km}$. Whilst an attempt was made to gather a representative collection of

198 reduction spheroids from both localities, inevitably there was some degree of sampling

199 bias toward average $(\sim 10 \mathrm{~cm})$ and larger than average reduction spheroids. With this

200 considered samples of a range of sizes $(4.5-16 \mathrm{~cm}$ in diameter) were collected and

201 analysed.

202 Eighteen reduction spheroids were prepared as polished blocks for non-destructive

203 mineralogical and geochemical analyses, whilst twenty others were used for x-ray

204 diffraction (XRD) analysis. Twenty-one samples of the host red-bed were also taken

205 from the Rainbow Valley unit through to the base of Red Bluff unit. Three of these

206 samples were then polished for non-destructive analyses; a red fluvial sandstone from

207 the RBU (RBU-HR-29), a white reduced fluvial sandstone from the RBU (RBU-HR-

208 23), and a red siltstone from the RVU (RVU-HR-17), whilst twenty-four samples were

209 powdered for XRD. Additionally, clay separates were collected from two of the samples

210 of Tumblagooda Sandstone that were also polished for petrographic analysis; one each

211 from a sample of red sandstone from the RBU (RBU-HR-29) and white sandstone from

212 the RBU (RBU-HR-23). These samples were lightly crushed, sieved, and clay-sized ( $<2$

$213 \mu \mathrm{m})$ particles were separated in deionised water.

214 Mineralogical and Geochemical Analysis

215 All the analyses performed in this study were conducted at the Commonwealth

216 Scientific and Industrial Research Organisation (CSIRO) Advanced Resource

217 Characterisation Facility at the Australian Resources Research Centre and at the John de

218 Laeter Centre at Curtin University in Perth, Western Australia. XRD analyses were 
conducted using a Bruker D4 ENDEAVOUR (Bruker Corporation, Billerica, MA, USA) with a LynxEye Detector and a cobalt x-ray tube. Reduction spheroid cores and Tumblagooda Sandstone host rock sample powders were analysed in steel ring holders at $5-90^{\circ} 2 \theta, 40 \mathrm{kV}$, and $35 \mathrm{~mA}$. The clay separates from two host sandstone samples were analysed at $2-35^{\circ} 2 \theta$ at $40 \mathrm{kV}$ and $35 \mathrm{~mA}$ on a low-background Si slide in parallel and random orientations. These samples were also analysed for expanding clays through the addition of ethylene glycol to the slides and rescanning under the same parameters. The data were analysed using the Bruker DIFFRAC.EVA XRD software and machine performance were evaluated using corundum standards and referenced using known dspacing of quartz within each sample.

All polished samples were investigated using reflected light microscopy with a Nikon LV100N POL (Nikon Instruments, Tokyo, Japan) to broadly define their microstructure, mineral composition, and textures. Additionally, elemental mapping was conducted using a Bruker M4 TORNADO (Bruker Corporation, Billerica, MA, USA) Micro-XRF mapper. Analyses were performed using a beam diameter and point spacing of $25 \mu \mathrm{m}$, with a dwell time between 5-10 ms. Further analysis of these samples was conducted using a Zeiss Ultra Plus (Carl Zeiss Microscopy GmbH, Jena, Germany) Field Emission Gun Scanning Electron Microscope (FEG-SEM), with energy-dispersive X-ray spectra collected using a Bruker XFlash 6 (Bruker Corporation, Billerica, MA,

238 USA) energy-dispersive spectrometer (EDS). Typically, a working distance of $\sim 6 \mathrm{~mm}$ was used; with an accelerating voltage of $5-20 \mathrm{kV}$ and a beam current of $690 \mathrm{~Pa}$. In addition, freshly broken samples were analysed using this SEM to observe the three-

241 dimensional nature of the mineral associations within the reduction spheroids and host

242 sandstone. The minerals were identified through semi-quantitative chemical analysis in 
243 combination with analysis of crystal morphologies and textures and then confirmed

244 through XRD and electron backscatter diffraction analysis (EBSD). EBSD analysis was

245 conducted on a Tescan Mira3 (TESCAN, Brno, Czech Republic) FEG-SEM fitted with

246 an Oxford Instruments Aztec (Oxford Instruments plc, Abingdon, UK) acquisition

247 system. These samples were coated with a thin carbon coat and analysed at a working

248 distance of $18.5 \mathrm{~mm}$, a stage tilt of $70^{\circ}$, and an accelerating voltage of $20 \mathrm{kV}$.

249

250

251

252

253

254

255

256

257

258

259

260

261

262

263

264

\section{Computed Tomography Analysis}

The samples were scanned in 3D by X-ray computed tomography (XCT) using a Siemens SOMATOM definition AS (Siemens AG, Berlin, Germany) medical scanner allowing the rapid $3 \mathrm{D}$ scanning of the reduction spheroids. The instrument was calibrated using air, water and a set of five in-house rock standards of known density that are suitable for mineral resources applications $\left(2.7\right.$ to $\left.4.3 \mathrm{~g} / \mathrm{cm}^{3}\right)$. The energy of the beam was set-up to have maximal phase contrast between the detrital grains and interstitial metalliferous minerals. The voxel size (i.e. pixel in 3D) was set-up to $300 \mathrm{x}$ $300 \times 100 \mu \mathrm{m}(\sim 0.5 \mathrm{~mm}$ spatial resolution) to allow entire coverage of the samples. The CT data was processed and analysed using ThermoFisher Avizo 3D data visualisation software. The workflows used in this study are discussed further by Godel et al. (2006) and Godel (2013).

\section{Results}

\section{Reduction Spheroid Occurrence and Appearance}

\section{Field Observations}

At the most reduction spheroid-rich horizons within the coastal exposures of the Tumblagooda Sandstone, reduction spheroids occur in densities of approximately 15 per 
$266 \mathrm{~m}^{2}$ (Fig. 1c) over a strike length of at least $2 \mathrm{~km}$. The reduction spheroids present in the

267 sand-rich RBU differ in appearance from those in the more clay-rich RVU (Fig. 1). The

268 reduction spheroids of the RBU commonly contain slightly smaller, relative to their

269 total volume, dark red-grey cores that are surrounded by reduction halos often

270 containing concentrically zoned mineralised rings (Fig. 1a/b). By contrast, the reduction

271 spheroids of the RVU typically contain larger dark grey cores within a beige reduction

272 halo that commonly does not contain any outward concentric zoning (Fig. 1c/d).

273 Throughout the Tumblagooda Sandstone, the reduction spheroids are commonly ovoid

274 in shape, elongated parallel to bedding structures in the rock and generally range from

$275 \quad 1-18 \mathrm{~cm}$ in diameter; with an average total diameter of $\sim 10 \mathrm{~cm}$ and an average total core

276 diameter of $\sim 4 \mathrm{~cm}$. Whilst the total reduction spheroid size is relatively consistent

277 between the RBU and RVU, generally the reduction spheroids of the RVU tend to have

278 slightly larger cores. It also worth noting that whilst reduction bands are occasionally

279 observed to occur in association with reduction spheroids (Fig. 1d), reduction bands do

280 not appear to have any specific genetic relationship to reduction spheroids as they are

281 common throughout the Tumblagooda Sandstone, and other red beds globally;

282 including where reduction spheroids are not observed. Instead the reduction bands most

283 likely formed as a result of the migration of genetically unrelated reducing fluids during

284 diagenesis (Parry et al., 2004).

\section{Computed Tomography Analysis}

286 The abundance of reduction spheroids facilitated the recovery of whole reduction

287 spheroid samples, allowing the first ever CT imaging of the three-dimensional structure

288 of a whole reduction spheroid to be conducted (Fig. 5). CT imaging demonstrates the

289 three-dimensional nature of reduction spheroids, with a dense spheroidal core that is 
290 slightly oblate and has therefore been vertically shortened or horizontally elongated.

291 Whilst all reduction spheroids are three-dimensional, it is relatively rare to observe a

292 whole reduction spheroid as any reduction spheroid in an outcrop with an observable

293 core must have been sufficiently eroded such that its internal core is visible.

294 Consequently, being able to observe the three-dimensional, internal structure of a whole

295 reduction spheroid is novel and can inform models for their formation and the relative

296 influence of basinal fluid flow, sediment permeability, and compaction on their

297 morphology and structure. Additional CT scan clips are also provided in the supporting

298 information.

299

300

301

302

303

304

305

306

307

\section{Mineralogy}

\section{X-Ray Diffraction}

Reduction spheroid cores are all relatively similar in mineralogy and dominated by quartz and microcline. Most reduction spheroids also contain haematite and illite; however, two samples (RBU-RS-17 and RBU-RS-39) lack a haematite signature. It is also interesting to note that there is variation in the width of haematite peaks, with some samples (RBU-RS-1) containing noticeably broader peaks. This is possibly due to variation in haematite crystallinity across samples, with wider peaks indicative of less crystalline haematite (Schwertmann and Latham, 1986). The detection limits associated with powder XRD restricted the detailed identification of less abundant minerals. These less abundant mineral phases were characterised using microscopy techniques.

Analysis of the clay separates from the two samples (RBU-HR-23 and RBU-HR-29) of Tumblagooda Sandstone host rock revealed that the clay fraction of the rock is dominated by illite; as indicated by a sharp illite peak at $10 \AA$ in the spectra. These samples are also characterised by the absence of the 12-15 $\AA$ peaks typical of smectite. 
314 The absence of interstratified expanding clays, such as smectite, within the illite was

315 further confirmed by the absence of shift of the $10 \AA$ peak following addition of

316 ethylene glycol to the samples (Srodon, 1980). Additional analysis of this illite, using

317 randomly oriented samples, showed that it is composed of the lower temperature one-

318 layer monoclinic (1M) polytype as it lacks any diagnostic two-layer monoclinic (2M)

319 peaks (Grathoff and Moore, 1996). The absence of 2M polytype illite confirms an

320 authigenic origin indicating that the illite formed due to heating during diagenesis

321 (Weaver, 1958). The temperature of this heating can be estimated by measuring the

322 crystallinity index of the illite in the samples using the illite peak width at half-height

323 (Eberl and Velde, 1989). This analysis found an illite crystallinity of 0.451 for the

324 sample of white reduced sandstone (RBU-HR-23), and 0.467 for the sample of red

325 oxidised sandstone (RBU-HR-29). These values correspond to a heating temperature of

$326 \sim 200^{\circ} \mathrm{C}$; accounting for the low smectite content within the illite in these samples, as

327 this temperature of diagenesis corresponds to an interstratified smectite content of only

$328 \sim 5 \%$ within the illite (Merriman and Frey, 1999).

329

330

331

332

333

334

335

336

337

\section{Optical and Scanning Electron Microscopy}

Petrographic analysis of the 18 polished reduction spheroids confirmed detrital quartz and K-feldspar are the dominant minerals within spheroid cores. Quartz grains commonly show clear secondary quartz overgrowths and sutured grain contacts. Kfeldspar grains range from fresh to pervasively weathered and are commonly replaced by interstitial illite. Intergranular porosity within the cores is filled with haematitic cement; occurring as a dense assemblage of coarse (10-200 $\mu \mathrm{m})$ interstitial microplaty haematite crystals $(\mathrm{MplH})(\mathrm{Fig} .6 \mathrm{a} / \mathrm{b})$ or fine haematite cement (crystals $<10 \mu \mathrm{m})$ that is commonly intergrown with illite (Fig. 6c). Dark grey cores are intensely cemented by a 
coarse $\mathrm{MplH}$ that commonly fills fractures within weathered K-feldspar grains (Fig. 6a), which reduces both intergranular and intragranular porosity. Reddish cores tend to be cemented by a combination of fine haematite and illite (Fig. 6d). However, the majority of the reduction spheroid cores contain both coarse $\mathrm{MplH}$ and fine red haematite; resulting in variably grey and red portions.

Both the cores and surrounding reduction halos of the reduction spheroids are observed to contain low volumes of secondary anatase occurring as clusters between quartz and K-feldspar grains throughout the samples. These clusters are generally composed of aggregates of several anatase crystals and display a variety of textures; ranging from round clusters $(50-200 \mu \mathrm{m})$ of needle-shaped crystals $(<10 \mu \mathrm{m}$, Fig. $6 \mathrm{e})$, trellis-like aggregates of acicular laths (Fig. 6f), to clusters of coarser $(<100 \mu \mathrm{m})$ crystals that are equant in basal section and bladed along their long axis (Fig. 6g). The clusters of coarse anatase crystals are commonly surrounded by very fine $(<1 \mu \mathrm{m})$ anatase aggregates (Fig. 6h). Additionally, the coarse anatase crystal often contain small $(\sim 1 \mu \mathrm{m})$ irregularly shaped uraninite inclusions (Fig. 7a).

Svanbergite $\left(\mathrm{SrAl}_{3}\left(\mathrm{PO}_{4}\right)\left(\mathrm{SO}_{4}\right)(\mathrm{OH})_{6}\right)$ and gorceixite $\left(\mathrm{BaAl}_{3}\left(\mathrm{PO}_{4}\right)\left(\mathrm{PO}_{3} \mathrm{OH}\right)(\mathrm{OH})_{6}\right)$ are aluminium-phosphate-sulphate (APS) minerals that occur within both the spheroid cores and reduction halos. Svanbergite is commonly observed to occur as isolated inclusions within the $\mathrm{MplH}$ in the cores. It is also present as small cubic euhedral crystals $(\sim 4 \mu \mathrm{m})$ in the illite matrix, and as aggregates filling internal porosity in quartz and K-feldspar grains (Fig. 7b/c). Gorceixite occurs almost exclusively in association with svanbergite, forming rims surrounding svanbergite crystals (Fig. 7d). Illite occurs throughout the reduction spheroids as the only clay mineral and the dominant interstitial phase in the beige reduction halo of the reduction spheroids and commonly infills weathered voids 
within grains of K-feldspar. Small anhedral authigenic monazite crystals $(<10 \mu \mathrm{m})$ occur as clusters of crystals commonly enveloped by quartz overgrowths or adhered to detrital grains (Fig. 7e).

For comparison with the reduction spheroids, three samples of Tumblagooda Sandstone host rock were petrographically analysed; a sample of red fluvial sandstone (RBU-HR29), reduced white fluvial sandstone (RBU-HR-23), and red siltstone (RVU-HR-17). All three samples are dominated by detrital quartz and K-feldspar, with illite being the principal interstitial phase. The primary difference between the sandstone (RBU) and the siltstone (RVU) is that the latter contains significantly more illite and its detrital quartz and K-feldspar grains are finer. Gorceixite and svanbergite are rare within the three host rock samples, though they do occur. The distribution of these two APS minerals through the samples is similar to those observed in the reduction spheroids. Svanbergite forms aggregates of fine subhedral-euhedral crystals adhered to quartz grains or isolated crystals dispersed throughout the illite matrix, whereas gorceixite occurs solely as zoned rims around svanbergite grains. Although present, these APS minerals are much less abundant within the host Tumblagooda Sandstone compared to the reduction spheroids. Haematite in the red sandstone and siltstone is present as extremely fine needles $(<1 \mu \mathrm{m})$ throughout the illite matrix, whereas it was not observed in the reduced white sandstone. Finally, unaltered detrital ilmenite grains $(\sim 100 \mu \mathrm{m})$ displaying magmatic exsolution textures (Fig. $7 \mathrm{f})$ are observed within the red sandstone and siltstone. However, ilmenite was not observed within the reduction spheroids or the reduced white sandstone sample. The above information on the mineralogy and nature of the occurrence of these minerals in the host rock Tumblagooda Sandstone and reduction spheroids is summarised in Table 1. 
387 Sandstone and reduction spheroids.

\begin{tabular}{ll}
\hline Mineral phase & Abundance and nature of occurrence \\
\hline Quartz & $\begin{array}{l}\text { Common. Primary. Dominant detrital mineral in } \\
\text { host rock and throughout reduction spheroids. }\end{array}$ \\
\hline K-feldspar & $\begin{array}{l}\text { Common. Primary. Abundant detrital mineral in } \\
\text { host rock and throughout reduction spheroids. }\end{array}$ \\
\hline Heavy minerals & $\begin{array}{l}\text { Common. Primary. Detrital zircon, monazite, } \\
\text { ilmenite, and rutile common in red host } \\
\text { sandstone. Detrital ilmenite, rutile, and monazite } \\
\text { are rare in white sandstone and reduction } \\
\text { spheroids. }\end{array}$ \\
\hline Common. Authigenic. Occurs throughout \\
reduction spheroids in aggregates of cubic \\
crystals filling interstitial space.
\end{tabular}

391 Cores of reduction spheroids contain abundant Fe (haematite), mainly as an interstitial 
393 enrichment reflects the predominance of $\mathrm{MplH}$ within the reduction spheroid cores.

394 Though Fe is observed within the host red sandstone surrounding the reduction

395 spheroids, it is significantly more abundant in the cores of the reduction spheroids. By

396 contrast, $\mathrm{Fe}$ is absent in the pale reduction halos, which are dominated by $\mathrm{Si}$ (quartz)

397 and K (K-feldspar). In some samples (RBU-RS-8, 50) weathered fractures in K-feldspar

398 grains are clearly penetrated by Fe (Fig. 6a/8b). Additionally, the concentric rings that

399 occur in some reduction spheroid samples (RBU-RS-11, 36, 43, and RVU-RS-55) are

400 similarly enriched in Fe but tend to be more sparsely mineralised than the cores; with

401 lower Fe-enrichment.

402 Thin bands of Ti-bearing phases occur consistently (RBU-RS-6, 50; Fig. 8a/b)

403 throughout several reduction spheroid samples. These Ti-bearing phases most likely

404 correspond to the previously discussed authigenic anatase. The Ti distribution follows

405 similarly oriented straight lines running parallel or sub-parallel to one another and to the

406 prevailing sedimentary fabric. These bands cross-cut the central mineralised spheroid

407 cores (RVU-RS-48 and RBU-RS-50) as well as the reduction halos. Although the Fe-

408 rich core is cross-cut by these thin bands of Ti, the Ti-enrichment is generally

409 discontinuous across it. In some cases (RBU-RS-7 and RVU-RS-55) the Fe-enrichment

410 also appears to disperse from the core and concentric rings along the sedimentary fabric

411 (Fig. 8c/d/e). 


\section{Comparisons with Typical Reduction Spheroids}

\section{Morphology}

415 The Tumblagooda Sandstone reduction spheroids resemble reduction spheroids from

416 other red beds around the world in several aspects. For instance, the slight horizontal

417 elongation of reduction spheroids in the Tumblagooda Sandstone (Fig. 5) and in

418 exposed reduction spheroids in outcrop, mirrors that observed by Mykura and Hampton

419 (1984); Hofmann (1990b); Lines et al. (1995); Spinks et al. (2010). This can be explained by the formation of the reduction spheroids prior to sediment compaction or due to improved fluid diffusion along sedimentary fabrics parallel to bedding structures (Hofmann, 1990b; Spinks et al., 2010). The latter explanation may account for the horizontal diffusion of mineralisation out from the cores of some of the Tumblagooda

424 Sandstone reduction spheroids and their elongation parallel to sedimentary structures (i.e. cross-bedding) (Fig. 8c/d/e). Cumulatively, these observations imply that the improved permeability along pre-existing non-horizontal sedimentary structures and the potential for basinal fluid migration along these structures during reduction spheroid formation impart a significant control on the morphology of a given reduction spheroid.

429 This information contradicts previous interpretations that reduction spheroids are oblate due to vertical shortening as a result of sediment compaction (Spinks et al., 2010).

431 The concentric rings present in reduction spheroids from the RBU also resemble the 432 zonation in reduction spheroids observed by Carter (1931); Hofmann (1990b); Lines et 433 al. (1995); Milodowski et al. (2002); Spinks et al. (2014), which also exhibit a 434 mineralogy consistent with the central core. An explanation for the formation of these concentric rings has not been offered. However, similar structures exist within 
436 carbonate concretions; which are similarly believed to form through the consumption of 437 organic matter by sub-surface microbial communities (Marshall and Pirrie, 2013; Plet et 438 al., 2016). Within carbonate concretions, this concentric zoning is typically interpreted 439 to be a growth feature related to the outward growth of concretions from a central 440 nucleus during discrete stages (Mozley, 1996; Marshall and Pirrie, 2013). Similarly, the 441 concentric rings present in the Tumblagooda Sandstone reduction spheroids, and 442 reduction spheroids from other localities, could reflect progressive changes in reduction spheroid forming processes and condition, including the intensity of microbial activity; availability of metals; and pore-water chemistry.

445 Despite strong similarities between the spheroids observed here and in previous studies,

446 a few discrepancies were also observed. Variations in terms of appearance and morphology of the reduction spheroids were observed within the Tumblagooda Sandstone, particularly between those hosted in the coarse fluvial sandstone of the RBU and the overlying siltstone of the RVU. Specifically, the reduction spheroids that occur

450 within the RVU contain larger cores that are more densely mineralised with $\mathrm{MplH}$, and consequently display a darker grey colour (Fig. 1). This finding contradicts observations made by Lines et al. (1995) on reduction spheroids from The Hopewell Group of New

453 Brunswick, where coarser grained units hosted larger reduction spheroids with

454 correspondingly larger cores. This relationship between grain size and reduction

455 spheroid size was accounted for by the increased porosity and permeability associated 456 with coarser grained sediment. However, the contradictory nature of the findings of the 457 present study and those of Lines et al. (1995), suggest that in the studied cases the effect 458 of grain size on porosity and permeability does not impart a critical control on the size 459 of reduction spheroids generally. In the present study, the larger cores within the finer 
460 grained clay-bearing siltstones of the RVU may be explained by the greater

461 concentration of trace metals within these units available for incorporation into

462 reduction spheroids' cores, when compared with the more quartz and feldspar-rich

463 sandstones in the RBU (Supp. info.; Pettijohn, 1963).

\section{Mineralogy and Geochemistry}

465 Compositionally, the reduction spheroids of the Tumblagooda Sandstone are unique in comparison to reduction spheroids previously reported from other localities. This is

467 because their cores are enriched in Fe due to their haematite-dominated mineralogy.

468 Haematite is an oxidised Fe phase, yet reduction spheroids form via the reductive

469 concentration of dissolved metals through the metabolic processes of DMRB (Spinks et

470 al., 2010). Therefore, haematite is a particularly uncommon constituent of typical reduction spheroids (Hofmann, 1991). One would expect that magnetite, a reduced Fe phase that is observed to form via the biomineralising activity of DMRB (Lovley, 1991; Lovley, 1993; Lovley et al., 2004), could be commonly observed in reduction spheroids, yet magnetite is also relatively rare in reduction spheroids. Overall, reduction spheroids are most often depleted in Fe in comparison to their red host sandstones (Hofmann, 1990a; Hofmann, 1990b; Hofmann, 1991). This makes the abundance of haematite, and the related Fe-enrichment, within the Tumblagooda Sandstone reduction spheroids' cores particularly exceptional. In addition, the presence of svanbergite, gorceixite,

479 authigenic anatase, and authigenic monazite within the Tumblagooda Sandstone reduction spheroids is also unique as none of these minerals have previously been observed in reduction spheroids. These mineral phases are, however, relatively minor in abundance in comparison to the $\mathrm{MplH}$ cement in the reduction spheroids and the

483 observation of these unique mineral phases may simply reflect the fact that the 
analytical techniques used in previous studies may not have allowed for the identification of relatively low abundance and fine-grained minerals such as svanbergite, gorceixite, and anatase.

Roscoelite $\left(\mathrm{K}(\mathrm{Al}, \mathrm{V}, \mathrm{Mg}, \mathrm{Fe})_{2}(\mathrm{Si}, \mathrm{Al})_{4} \mathrm{O}_{10}(\mathrm{OH})_{2}\right)$ is a vanadiferous mica that is common in previously studied reduction spheroids; particularly those from Devonian red beds (Hofmann, 1991; Van Panhuys-Sigler et al., 1996; Spinks et al., 2010; Spinks et al., 2014; Parnell et al., 2015b), but is conspicuously absent from the Tumblagooda Sandstone reduction spheroids. Despite their predominance within reduction spheroids from other localities (Hofmann, 1990a; Hofmann, 1990b; Hofmann, 1991), reduced mineral phases are uncommon within the Tumblagooda Sandstone reduction spheroids, except for minor amounts of uraninite (Fig. 7a). Finally, it is noteworthy that, unlike reduction spheroids from other localities (Harrison, 1975; Harrison et al., 1983; Hofmann, 1990b; Spinks et al., 2014), reduction spheroids of the Tumblagooda Sandstone contain no evidence of even trace quantities of any base metal phases.

\section{Record of Diagenetic Conditions}

\section{Evidence of an acidic microenvironment during reduction spheroid formation}

Reductive activity of DMRB during early diagenesis within the reduction spheroids would have created a microenvironment by controlling the redox conditions at the $\mu \mathrm{m}-$ scale. This would have also generated geochemical conditions conducive to the authigenic formation of svanbergite and anatase within the Tumblagooda Sandstone. Authigenic anatase is interpreted to be a product of the local mobilisation of Ti from the unaltered primary titaniferous minerals that are observed within the red Tumblagooda Sandstone host rock (ilmenite, Fig. 7f), but are no longer observed within the reduction spheroids. Additionally, the mobilisation of Ti from primary ilmenite and 
508 reprecipitation elsewhere within the reduction spheroids as anatase may account for 509 discontinuity of Ti-rich bands across the Fe-rich cores of the reduction spheroids within 510 the XRF map of RBU-RS-50 (Fig. 8b). These Ti-rich bands represent horizons of 511 detrital titaniferous heavy minerals. Due to the immobility of Ti (Schulz et al., 2016),

512 the anatase banding is believed to be inherited from the primary distribution of the

513 ilmenite from which it was derived. However, the extreme immobility of Ti necessitates 514 strongly acidic conditions $(\mathrm{pH}<2)$ to mobilise it from primary ilmenite (Sugitani et al., 515 1996). Therefore, the Ti discontinuity across the centre of the reduction spheroid cores 516 is due to the fact that this was the most intensely reducing and acidic portion of

517 Tumblagooda Sandstone reduction spheroids and, consequently, was the only portion

518 where conditions were sufficiently acidic to mobilise Ti. Spinks et al. (in review) have 519 proposed that humic acids would be necessary for reduction spheroid genesis as a 520 chelator to locally mobilise metals and allow reduction spheroid formation through 521 microbial activity. The presence of humic acids could also have provided the acidic 522 conditions necessary to locally mobilise Ti within reduction spheroid cores. Humic 523 acids are also commonly proposed as a chelator in the wider context of microbial metal 524 reduction in nature, particularly because of their relative abundance in soils and sediments (Lovley et al., 1996; Lovley et al., 1998). These humic acids would have

526 been derived from the microbial degradation of the detrital organic matter that acts as

527 the reducing agent and energy source in reduction spheroid genesis. Further evidence of 528 these intensely acidic conditions is provided by the presence of the svanbergite that is 529 particularly common throughout the reduction spheroids. Svanbergite, and other APS 530 minerals, are typically associated with strongly acidic migrating fluids, when observed 531 in sediments (Dill, 2001; Benito et al., 2005; Galán-Abellán et al., 2013; Salama, 2014). 
532 Under reducing conditions, svanbergite becomes stable only under increasingly acidic

533 conditions (Gaboreau et al., 2005).

\section{Reduction spheroid reoxidation}

535 Abundant haematite throughout the cores of the Tumblagooda Sandstone reduction

536 spheroids is most likely a product of a later stage reoxidation, following the cessation of reduction by DMRB and exhaustion of the available organic matter in the reduction spheroids. As such, the precursor of the haematite in these reduction spheroids was probably fine-grained biogenic magnetite; a common product of the biomineralising metabolic processes of DMRB (Lovley, 1991; Lovley et al., 2004). Once reducing

541 conditions had ceased within the reduction spheroids, this biogenic magnetite may have been oxidised, as a result of exposure to oxidising conditions within the red bed.

Whether this is related to the background oxidising conditions of the red bed or exposure to an oxidising fluid during diagenesis is difficult to determine. However, the prior explanation fails to account for why reduction spheroids in other red beds have not

546 similarly been reoxidised. Therefore, it is interpreted here that the Tumblagooda

547 Sandstone reduction spheroids were reoxidised due to exposure to oxidising high-

548 temperature basinal fluids during diagenesis. The lack of comparable reoxidation or

549 other diagenetic overprinting in reduction spheroids within other red beds may be

550 attributable to the relatively extensive deep burial and diagenesis of the Tumblagooda

551 Sandstone, which is discussed in the next section. This contrasts with roscoelite-bearing

552 reduction spheroids from various localities that are interpreted to have been exposed to

553 maximum burial temperatures of $<150{ }^{\circ} \mathrm{C}$ or present evidence of limited basinal fluid-

554 rock interaction (Hanly et al., 2003; Parnell et al., 2015b; Parnell et al., 2016; Parnell et

555 al., 2018). Additionally, Fe-enrichment and the formation of Fe-oxide phases must have 
556 occurred during diagenesis; after the weathering of K-feldspar grains. This is evidenced 557 by the penetration of $\mathrm{MplH}$ and Fe-enrichment through weathered fractures in these $\mathrm{K}$ 558 feldspar grains (Fig. 6a/8b). This later stage of reoxidation may account for the absence 559 of minerals such as roscoelite or the other reduced phases that are characteristic of

560 reduction spheroids from other localities but are not observed within the Tumblagooda

561 Sandstone. It is likely that other reduced phases formed during active reduction within

562 the reduction spheroids, but the later oxidising processes that formed the $\mathrm{MplH}$

563 currently present in the reduction spheroid cores would have destabilised and altered

564 such minerals. This is with the exception of uraninite, which forms exclusively under

565 reducing conditions (Janeczek and Ewing, 1992). It is proposed that uraninite is

566 preserved within these reduction spheroids due to its occurrence as inclusions within

567 larger grains of authigenic anatase, which may have protected it from exposure to 568 oxidising conditions.

\section{Reduction spheroid heating}

570 Oxidation of reduction spheroids would have been synchronous with and followed by 571 the progressive burial of the host red bed. Quartz overgrowth cement is ubiquitous in 572 sandstones globally (McBride, 1989), and well developed quartz overgrowths are

573 present within the reduction spheroids just as they are within the host Tumblagooda

574 Sandstone. Inclusions of early diagenetic minerals are present within these quartz

575 overgrowths whilst none of the hypothesised reduced phases have been preserved in the 576 overgrowths. This implies that they were altered prior to the host rock being buried,

577 leading to the formation of quartz overgrowths. Whilst quartz cementation is generally 578 proposed to form at temperatures between $60-100{ }^{\circ} \mathrm{C}(\mathrm{McBride}, 1989)$, the majority of 579 quartz cementation occurs at temperatures greater than $90-100{ }^{\circ} \mathrm{C}$. Previous work on the 
580 Tumblagooda Sandstone proposed that the finalisation of its quartz cementation took

581 place at temperatures of $>100^{\circ} \mathrm{C}$ and depths of $>3 \mathrm{~km}$, in the presence of meteoric

582 fluids (Bjorlykke and Egeberg, 1993; Trewin and Fallick, 2000). Within the

583 Tumblagooda Sandstone reduction spheroids, the majority of quartz cementation

584 appears to have taken place prior to the development of $\mathrm{MplH}$ and illite.

585 Microplaty haematite in sedimentary rocks exclusively forms as a product of the heating

586 and recrystallisation of fine grained and amorphous precursor Fe-bearing oxides and

587 hydroxides. Additionally, estimates of the temperature at which $\mathrm{MplH}$ begins to form

588 typically range from $80-100{ }^{\circ} \mathrm{C}$ and up to $150{ }^{\circ} \mathrm{C}$ (Catling and Moore, 2003; Morris,

589 2012). The oxidation of fine-grained biogenic magnetite within reduction spheroid cores

590 would have provided a suitable fine-grained Fe-oxide precursor to $\mathrm{MplH}$ as the

591 dominant mineral within reduction spheroids. This fine-grained oxidised Fe oxide

592 precursor could then have been thermally coarsened to MplH during burial, with the

593 potential driver of both this reoxidation and thermal coarsening being high temperature

594 oxidising basinal fluids. It is interpreted that the majority of the $\mathrm{MplH}$ formed after the

595 majority of the quartz cementation had occurred as, texturally, the $\mathrm{MplH}$ appears to

596 postdate quartz overgrowths in the spheroids. Therefore, because the majority of the

597 quartz cementation in the Tumblagooda Sandstone took place at $>100{ }^{\circ} \mathrm{C}$, the $\mathrm{MplH}$ is

598 similarly interpreted to have formed at $>100{ }^{\circ} \mathrm{C}$, following further burial. Considering

599 this, the presence of fine grained red haematite within some reduction spheroid cores is

600 interpreted to have formed at cooler temperatures after the formation of the $\mathrm{MplH}$;

601 possibly by the leaching and reprecipitation of Fe from $\mathrm{MplH}$ by relatively cool fluids

$602\left(<100^{\circ} \mathrm{C}\right)$ after the exhumation and resultant cooling of the Tumblagooda Sandstone

603 (Morris, 2003). This information and the paragenetic sequence of mineral formation in 
604 the genesis of the Tumblagooda Sandstone reduction spheroids are summarised in Fig. 6059

606 Further evidence of the heating of the Tumblagooda Sandstone reduction spheroids is 607 provided by authigenic illite, which most likely formed as a product of the illitisation of 608 smectite due to burial-related heating (Trewin and Fallick, 2000; Worden and Morad, 609 2003). Illitisation of smectite is a gradual process that begins at diagenetic temperatures 610 as low as $\sim 40{ }^{\circ} \mathrm{C}$ (Eberl, 1993), though this depends on several factors, including time 611 and K-availability (Bjorlykke, 1998). Nonetheless, the illite crystallinity results for the 612 host sandstone consistently record peak diagenetic temperatures of $\sim 200{ }^{\circ} \mathrm{C}$; indicating 613 authigenic illite formation was a process that continued through deep burial. The 614 presence of this highly crystalline illite with low smectite content, along with the 615 aforementioned $\mathrm{MplH}$ and quartz cementation point unequivocally to the deep burial 616 and heating of these reduction spheroids. This is also supported by geochemical and 617 petrographic analysis that suggested the dolomitisation and formation of anhydrite 618 cements within the overlying Dirk Hartog Group occurred at relatively high 619 temperatures during burial (El-Tabakh et al., 2004).

620 The thermal history of the Tumblagooda Sandstone is not particularly well constrained; 621 with apatite fission track analysis constraining its maximum palaeotemperature to $>110$ $622{ }^{\circ} \mathrm{C}$ (Ghori et al., 2005). Theoretical basin modelling of the 'Quail 1' drill hole from the 623 Merlinleigh sub-basin and the 'Coburn 1' drill hole from the Gascoyne Platform of the 624 Southern Carnarvon Basin constrained the peak burial temperature of horizons of the 625 Tumblagooda Sandstone to $\sim 110^{\circ} \mathrm{C}$ and $\sim 220^{\circ} \mathrm{C}$, respectively (Ghori, 1999). This 626 modelling was based largely on the extrapolation of thermal maturity data from 627 overlying units and bottom-hole temperature measurements; leading to a relatively 
imprecise estimate of palaeotemperature (Deming, 1989). Further, palaeotemperature estimates of portions of the Tumblagooda Sandstone present in the Merlinleigh Subbasin are arguably not applicable to the Tumblagooda Sandstone in Kalbarri, due to their presence in a different sub-basin. This study therefore provides valuable constraints on the thermal history of the Tumblagooda Sandstone; supporting previous assertions regarding the exposure of portions of the Tumblagooda Sandstone to temperatures of $\sim 200{ }^{\circ} \mathrm{C}$ and providing the first narrow, and relatively reliable, constraints on the peak heating of the Tumblagooda Sandstone.

\section{Research Significance and Implications}

This work re-evaluates existing genetic models for reduction spheroids by considering modifying processes relevant subsequent to the cessation of microbial activity. Whereas existing models for reduction spheroid genesis assume formation is complete upon the exhaustion of organic matter within their cores and the corresponding cessation of active bacterial metal reduction (Spinks et al., 2010; Parnell et al., 2015b), this work shows for the first time that deep basinal diagenetic processes can affect the composition of reduction spheroids long after their original formation. Not only is this important in understanding the genesis of reduction spheroids generally as it adds a new component to the existing reduction spheroid genetic model, but it has significant implications for studies that utilise reduction spheroids. This is particularly key in studies where reduction spheroids are used as biomarkers for DMRB in terrestrial environments, based upon their enrichment in redox-sensitive metals and reduced authigenic mineral phases (Spinks et al., 2010; Parnell et al., 2015a). Particularly pertinent examples of such studies include those where reduction spheroids are used as biomarkers for life's earliest colonisation of the terrestrial environment through DMRB 
652 or in the search for signs of primitive extraterrestrial life, such as in the case of the Mars 6532020 rover (Weber et al., 2006; Spinks et al., 2010; Thompson et al., 2014; Parnell et 654 al., 2015a). This is especially pertinent due to the growing broad interest in Martian 655 geology, particularly as it relates to the search for evidence of ancient life in the Martian 656 geological record. This work is made even more relevant by the noted plausibility of 657 bacterial metal reduction as a metabolic process for Martian life (Weber et al., 2006). If 658 mineralogical analysis of any reduction spheroids discovered in studies searching for 659 evidence of DMRB were to observe oxidised mineral phases within reduction 660 spheroids, they may misinterpret that such features are not biomarkers for DMRB when 661 in fact their original reduced mineral composition has simply been altered. This is 662 similarly an important consideration where reduction spheroids would potentially be 663 used in a mineral exploration setting, where their initial composition would potentially 664 be used as a pathfinder for regional metal anomalies (Spinks et al., 2014; Parnell et al., 665 2015b; Parnell et al., 2016).

666 It is proposed that, based on the findings of this study, the potential for reduction 667 spheroid alteration could provide insights into the diagenetic conditions experienced by 668 their host formations during burial. This has particular potential in quartz-dominated 669 sediments, which may not record diagenetic processes with any fidelity due to their 670 particularly non-reactive composition. The MplH-rich mineralogy present in the 671 Tumblagooda Sandstone reduction spheroids suggests exposure to elevated diagenetic temperatures $\left(>100{ }^{\circ} \mathrm{C}\right)$ in the presence of oxidising basinal fluids. This compliments

673 evidence from illite crystallinity analysis and the presence of very well-developed 674 quartz cementation to suggest that the Tumblagooda Sandstone reached a peak burial 675 temperature $\sim 200{ }^{\circ} \mathrm{C}$. Whilst of more regional significance, these data provide the first 
676

677

678

679

680

681

682

683

684

685

686

687

688

689

690

691

692

693

694

695

696

697

698

699

tight constraints on the poorly constrained diagenetic history of the Tumblagooda Sandstone and may have broader implications for the development of the Western Australian margin. This is due to the Tumblagooda Sandstone's position as the basal unit in the Southern Carnarvon and Perth Basins and consequent exposure to several major rifting events during the evolution of these basins (Ghori, 1999; Mory et al., 2003; Markwitz et al., 2017).

\section{Conclusions}

This study provides the first analysis of the abundant reduction spheroids that occur through the Tumblagooda Sandstone; indicating that they are noteworthy for their atypical composition. Geochemical and petrographic analyses reveal that the reduction spheroids' cores are strongly enriched in Fe; with the dominant authigenic mineral being microplaty haematite occurring between grains of detrital quartz and K-feldspar. However, authigenic anatase, uraninite, svanbergite, gorceixite, and monazite are also observed as minor phases throughout the reduction spheroid cores. Unlike reduction spheroids from other localities, no base metal phases or roscoelite are observed within Tumblagooda Sandstone spheroid cores. The occurrence of oxidised microplaty haematite throughout all of the reduction spheroids' cores is both unique and difficult to reconcile with a model for reduction spheroid genesis via DMRB. As such, it is proposed that the reduction spheroids of the Tumblagooda Sandstone were oxidised during diagenesis, subsequent to their initial formation, with the microplaty haematite in the reduction spheroids having formed through the reoxidation and heating of finegrained biogenic magnetite. During this process it is likely that other reduced phases, such as roscoelite or base metal phases, which are characteristic of reduction spheroids from other localities, were destroyed. The potential for reduction spheroid reoxidation 
700

701

702

703

704

705

706

707

708

709

710

711

712

713

714

715

716

717

718

719

720

721

722

723

724

725

726

727

post-formation has not previously been considered in other studies and resultantly

provides new insights into the genesis of reduction spheroids more broadly.

Consequently, it is important that future reduction spheroid studies consider the

currently unrecognised potential for the pervasive post-formation alteration of reduction spheroids. This is important to consider when attempting to utilise reduction spheroids as evidence of DMRB based on their reduced mineralogy. This is a key consideration in studies where reduction spheroids are used as mineralogical record of the metabolic processes of ancient DMRB; for example, in the search for evidence of the early colonisation of the terrestrial biosphere or signs of ancient life on Mars. However, it is proposed here that due to their potential for post-formation alteration, reduction spheroids could also provide a unique record of the evolution of redox conditions in red beds through detailed mineralogical analysis. More locally, this study also provides insights into the understudied diagenesis of the Tumblagooda Sandstone, including the first reliable and narrow constraints on its thermal history. As the Tumblagooda Sandstone is the basal unit of the Perth and Carnarvon basins these new constraints on burial and broader diagenesis may have important implications for understanding the evolution of these basins.

\section{References}

Benito, M.I., De la Horra, R., Barrenechea, J.F., López-Gómez, J., Rodas, M., Alonso-Azcárate, J., Arche, A. and Luque, J. (2005) Late Permian continental sediments in the SE Iberian Ranges, eastern Spain: Petrological and mineralogical characteristics and palaeoenvironmental significance. Palaeogeography,

Palaeoclimatology, Palaeoecology, 229, 24-39.

Bjorlykke, K. (1998) Clay mineral diagenesis in sedimentary basins - a key to the prediction of rock properties. Examples from the North Sea Basin. Clay Minerals, 33, 15-34.

Bjorlykke, K. and Egeberg, P.K. (1993) Quartz Cementation in Sedimentary Basins. The American Association of Petroleum Geologists Bulletin, 77, 1538-1548. 
Carter, G.E.L. (1931) An occurrence of vanadiferous nodules in the Permian beds of South Devon. Mineralogical Magazine, 609-613.

Catling, D.C. and Moore, J.M. (2003) The nature of coarse-grained crystalline hematite and its implications for the early environment of Mars. Icarus, 165, 277-300. Deming, D. (1989) Application of bottom-hole temperature corrections in geothermal studies. Geothermics, 18, 775-786. Dill, H.G. (2001) The geology of aluminium phosphates and sulphates of the alunite group minerals: a review. Earth-Science Reviews, 53, 35-93. Eberl, D.D. (1993) Three Zones for Illite Formation during Burial Diagenesis and Metamorphism. Clays and Clay Minerals, 41, 26-37.

738 Eberl, D.D. and Velde, B. (1989) Beyond The Kubler Index. Clay Minerals, 24, 571-

\section{7.}

740 El-Tabakh, M., Mory, A.J., Schreiber, B.C. and Yasin, R. (2004) Anhydrite cements after dolomitization of shallow marine Silurian carbonates of the Gascoyne Platform, Southern Carnarvon Basin, Western Australia. Sedimentary Geology, 164, 75-87. Fitzsimons, I.C.W. (2001) The Neoproterozoic evolution of Australia's western margin. In: From Basins to Mountains: Rodinia at the turn of the Century, $\mathbf{6 5}$. Geological Society of Australia, Abstracts, Perth, Western Australia.

Gaboreau, S., Beaufort, D., Vieillard, P. and Partier, P. (2005) Aluminum phosphate-sulfate minerals associated with Proterozoic unconformity-type uranium deposits in the East Alligator River uranium field, Northern Territories, Australia. The Canadian Mineralogist, 43, 813-827.

\section{Galán-Abellán, A.B., Barrenechea, J.F., Benito, M.I., De la Horra, R., Luque, J.,} Alonso-Azcárate, J., Arche, A., López-Gómez, J. and Lago, M. (2013) Palaeoenvironmental implications of aluminium phosphate-sulphate minerals in EarlyMiddle Triassic continental sediments, SE Iberian Range (Spain). Sedimentary Geology, 289, 169-181.

Ghori, K.A.R. 1999. Silurian-Devonian petroleum source-rock potential and thermal history, Carnarvon Basin, Western Australia, Geological Survey of Western Australia, Perth, Western Australia.

Ghori, K.A.R., Mory, A.J. and Iasky, R.P. (2005) Modeling petroleum generationin the Paleozoic of the Carnarvon Basin, Western Australia: Implications for prospectivity. AAPG Bulletin, 89, 27-40.

Godel, B. (2013) High resolution X-ray computed tomography and its application to ore deposits: from data acquisition to quantitative three-dimensional measurements with case studies from Ni-Cu-PGE deposits. Economic Geology, 108, 2005-2020.

Godel, B., Barnes, S.J. and Maier, W.D. (2006) 3-D distribution of sulphide minerals in the Merensky Reef (Bushveld Complex, South Africa) and the JM Reef (Stillwater Complex, USA) and their relationship to microstructures using X-ray computed tomography. Journal of Petrology, 47, 1853-1872.

768 Grathoff, G.H. and Moore, D.M. (1996) Illite Polytype Quantificationg Using

769 Wildfire C Calculated X-ray Diffraction Patterns. Clays and Clay Minerals, 44, 835770842.

771 Hanly, A.J., Geboy, N.J., Hiatt, E.E. and Kyser, K. (2003) Diagenesis, stratigraphy,

772 paleohydrology, and lead isotope study of the Proterozoic Sibley Group, Western

773 Ontario. In: Geological Society of America Annual Meeting, 35, pp. 234. Geological

774 Society of America Seattle. 
Harrison, R.K. 1975. Concretionary Concentrations of the Rarer Elements in PermoTriassic Red Beds of South-west England, Institute of Geological Sciences, London. Harrison, R.K., Old, R.A., Styles, M.T. and Young, B.R. 1983. Coffinite in nodules from the Mercia Mudstone Group (Triassic) of the IGS Knowle Borehole, West Midlands, Institute of Geological Sciences, London.

Hocking, R.M. 1991. The Silurian Tumblagooda Sandstone, Western Australia, Geological Survey of Western Australia, Perth, Western Australia.

Hocking, R.M. 2000. Geology of the Southern Carnarvon Basin, Western Australia a field guide, Geological Survey of Western Australia, Perth, Western Australia. Hocking, R.M. 2006. Geology of the Kalbarri area - a field guide, Geological Survey of Western Australia, Perth, Western Australia.

Hocking, R.M., Moors, H.T. and Van De Graaff, W.J.E. 1987. Geology of the Carnarvon Basin Western Australia, Geological Survey of Western Australia, Perth. Hofmann, B.A. 1990a. Reduction spheres in hematitic rocks from northern Switzerland: implications for the mobility of some rare elements, National Cooperative for the Disposal of Radioactive Waste, Wettingen, Switzerland.

Hofmann, B.A. (1990b) Reduction spheroids from northern Switzerland: Mineralogy, geochemistry and genetic models. Chemical Geology, 81, 55-81.

Hofmann, B.A. (1991) Mineralogy and Geochemistry of Reduction Spheroids in Red Beds. Mineralogy and Petrology, 44, 107-124.

Hofmann, B.A. 1999. Geochemistry of Natural Redox Fronts - A Review, National Cooperative for the Disposal of Radioactive Waste, Wettingen, Switzerland. Iasky, R.P., D'Ercole, C., Ghori, K.A.R., Mory, A.J. and Lockwood, A.M. 2003. Structure and petroleum prospectivity of the Gascoyne Platform, Western Australia, Western Australia Geological Survey, Perth.

Iasky, R.P. and Mory, A.J. 1999. Geology of the Gascoyne Platform Southern Carnarvon Basin Western Australia, Geological Survey of Western Australia, Perth, Western Australia.

Janeczek, J. and Ewing, R.C. (1992) Dissolution and alteration of uraninite under reducing conditions. Journal of Nuclear Materials, 190, 157-173.

Kettanah, Y.A., Mory, A.J., Wach, G.D. and Wingate, M.T.D. (2015) Provenance of the Ordovician-lower Silurian Tumblagooda Sandstone, Western Australia. Australian Journal of Earth Sciences, 62, 817-830.

\section{Lines, A.W., Parnell, J. and Mossman, D.J. (1995) Reduction spheroids from the} Upper Carboniferous Hopewell Group, Dorchester Cape, New Brunswick: notes on geochemistry, mineralogy and genesis. Atlantic Geology, 159-172.

Lovley, D.R. (1991) Magnetite Formation During Microbial Dissimilatory Iron Reduction. In: Iron Biominerals (Eds R.B. Frankel and R.P. Blakemore), pp. 151-166. Springer Science, New York, USA.

Lovley, D.R. (1993) Dissimilatory Metal Reduction. Annual Review of Microbiology, 263-290.

Lovley, D.R., Coates, J.D., Blunt-Harris, E.L., Phillips, E.J.P. and Woodward, J.C. (1996) Humic substances as electron acceptors for microbial respiration. Nature, 382, 445-448.

Lovley, D.R., Fraga, J.L., Blunt-Harris, E.L., Hayes, L.A., Phillips, E.J.P. and Coates, J.D. (1998) Humic Substances as a Mediator for Microbially Catalyzed Metal Reduction. Acta Hydrochimica et Hydrobiologica, 26, 152-157. 
Lovley, D.R., Holmes, D.E. and Nevin, K.P. (2004) Dissimilatory Fe(III) and Mn(IV) Reduction. Advances in Microbial Physiology, 49, 219-286. Markwitz, V., Kirkland, C.L., Wyrwoll, K.H., Hancock, E.A., Evans, N.J. and Lu, Y. (2017) Variations in Zircon Provenance Constrain Age and Geometry of an Early Paleozoic Rift in the Pinjarra Orogen, East Gondwana. Tectonics, 36, 2477-2496. Marshall, J.D. and Pirrie, D. (2013) Carbonate concretions-explained. Geology Today, 29, 53-62.

Martin, D.M., Johnson, S.P., Riganti, A. and Hogen-Esch, J. (2016) 1:500 000 State interpreted bedrock geology of Western Australia (Ed S.R. White). Geological Survey of Western Australia, Perth.

McBride, E.F. (1989) Quartz Cement in Sandstone: A Review. Earth-Science Reviews, 26, 69-112.

McNamara, K.J. (2014) First Footfall. In: Geoscientist, pp. 10-15. Geological Society of London, London, UK.

Merriman, R.J. and Frey, M. (1999) Patterns of Very Low-Grade Metamorphism in Metapelitic Rocks. In: Low-Grade Metamorphism (Eds M. Frey and D. Robinson), pp. 61-107. Blackwell Publishing Ltd., Oxford, UK.

Milodowski, A.E., Styles, M.T., Horstwood, M.S.A. and Kemp, S.J. 2002. Alteration of uraniferous and native copper concretions in the Permian mudrocks of south Devon, United Kingdom, Swedish Nuclear Fuel and Waste Management Company, Stockholm. Morris, R.C. (2003) Iron ore genesis and post-ore metasomatism at Mount Tom Price. Transactions of the Institutions of Mining and Metallurgy: Section B, 112, 56-67.

Morris, R.C. (2012) Microplaty hematite - its varied nature and genesis. Australian Journal of Earth Sciences, 59, 411-434.

Mory, A.J. and Hocking, R.M. 2008. Geology of the Kalbarri and Mingenew Areas A Field Guide, Geological Survey of Western Australia, Perth, Western Australia. Mory, A.J., Iasky, R.P. and Ghori, K.A.R. 2003. A summary of the geological evolution and petroleum potential of the Southern Carnarvon Basin, Western Australia, Western Australia Geological Survey, Perth.

Mozley, P.S. (1996) The internal structure of carbonate concretions in mudrocks: a critical evaluation of the conventional concentric model of concretion growth. Sedimentary Geology, 103, 85-91.

Mykura, H. and Hampton, B.P. (1984) On the mechanism of formation of reduction spots in the Carboniferous/Permian red beds of Warwickshire. Geological Magazine, 71-74.

Parnell, J. (2017) Tellurium and Selenium in Mesoproterozoic red beds. Precambrian Research, 305, 145-150.

Parnell, J., Brolly, C., Spinks, S. and Bowden, S. (2015a) Metalliferous Biosignatures for Deep Subsurface Microbial Activity. Origins of Life and Evolution of Biospheres, 46, 107-118.

Parnell, J., Spinks, S. and Bellis, D. (2016) Low-temperature concentration of tellurium and gold in continental red bed successions. Terra Nova, 221-227.

Parnell, J., Spinks, S. and Brolly, C. (2018) Tellurium and selenium in Mesoproterozoic red beds. Precambrian Research, 305, 145-150.

Parnell, J., Still, J., Spinks, S. and Bellis, D. (2015b) Gold in Devono-Carboniferous red beds of northern Britain. Journal of the Geological Society, 173, 245-248.

Parry, W.T., Chan, M.A. and Beitler, B. (2004) Chemical bleaching indicates episodes of fluid flow in deformation bands in sandstone. AAPG Bulletin, 88, 175-191. 
870 Pettijohn, F.J. (1963) Chemical Composition of Sandstones - Excluding Carbonate and

871 Volcanic Sands. In: Data of Geochemistry (Ed M. Fleischer), 440, pp. 1-21. US

872 Government Printing Office, Washington, DC.

873 Plet, C., Grice, K., Pagès, A., Ruebsam, W., Coolen, M.J.L. and Schwark, L. (2016)

874 Microbially-mediated fossil-bearing carbonate concretions and their significance for

875 palaeoenvironmental reconstructions: A multi-proxy organic and inorganic geochemical

876 appraisal. Chemical Geology, 426, 95-108.

877 Salama, W. (2014) Paleoenvironmental significance of aluminum phosphate-sulfate

878 minerals in the upper Cretaceous ooidal ironstones, E-NE Aswan area, southern Egypt.

879 International Journal of Earth Sciences, 103, 1621-1639.

880 Schulz, H., Wirth, R. and Schreiber, A. (2016) Nano-Crystal Formation of TiO2

881 Polymorphs Brookite and Anatase Due To Organic-Inorganic Rock-Fluid Interactions.

882 Journal of Sedimentary Research, 86, 59-72.

883 Schwertmann, U. and Latham, M. (1986) Properties of iron oxides in some New

884 Caledonian oxisols. Geoderma, 39, 105-123.

885 Spinks, S., Parnell, J. and Bowden, S.A. (2010) Reduction spots in the

886 Mesoproterozoic age: implications for life in the early terrestrial record. International

887 Journal of Astrobiology, 9, 209-216.

888 Spinks, S., Parnell, J. and Still, J.W. (2014) Redox-controlled selenide mineralization 889 in the Upper Old Red Sandstone. Scottish Journal of Geology, 50, 173-182.

890 Spinks, S., Schmid, S., White, A.J., Parnell, J., Brolly, C., Pagès, A. and Revie, D.

891 (in review) Head for the red beds! Earth's earliest colonisation of terrestrial

892 environments by iron-reducing bacteria.

893 Srodon, J. (1980) Precise Identification of Illite/Smectite Interstratifications by X-ray

894 Powder Diffraction. Clays and Clay Minerals, 28, 401-411.

895 Sugitani, K., Horiuchi, Y., Adachi, M. and Sugisaku, R. (1996) Anomalously low

$896 \mathrm{Al}_{2} \mathrm{O}_{3} / \mathrm{TiO}_{2}$ values for Archean cherts from the Pilbara Block, Western Australia -

897 possible evidence for extensive chemical weathering on the early earth. Precambrian

898 Research, 80, 49-76.

899 Thompson, D.R., Allwood, A., Assaid, C., Flannery, D., Hodyss, R., Knowles, E.

900 and Wade, L. (2014) Adaptive Sampling for Rover X-ray Lithochemistry. In:

901 International Symposium on Artificial Intelligence, Robotics, and Automation in Space,

902 Montreal.

903 Trewin, N.H. (1993a) Controls on fluvial deposition in mixed fluvial and aeolian facies

904 within the Tumblagooda Sandstone (Late Silurian) of Western Australia. Sedimentary

905 Geology, 85, 387-400.

906 Trewin, N.H. (1993b) Mixed aeolian sandsheet and fluvial deposits in the

907 Tumblagooda Sandstone, Western Australia. In: Characterisation of Fluvial and

908 Aeolian Resevoirs, pp. 219-230. Geological Society of London, London, UK.

909 Trewin, N.H. and Fallick, A.E. (2000) Quartz cement origins and budget in the

910 Tumblagooda Sandstone, Western Australia. In: Quartz Cementation in Sandstones

911 (Eds R.H. Worden and S. Morad). Wiley-Blackwell, Hoboken, USA.

912 Trewin, N.H. and McNamara, K.J. (1995) Arthropods invade the land: trace fossils

913 and palaeoenvironments of the Tumblagooda Sandstone (?late Silurian) of Kalbarri,

914 Western Australia. Transactions of the Royal Society of Edinburgh: Earth Sciences, 85,

915 177-210. 
916 Van Panhuys-Sigler, M., Trewin, N.H. and Still, J. (1996) Roscoelite associated with

917 reduction spots in Devonian red beds, Gamrie Bay, Banffshire. Scottish Journal of

918 Geology, 32, 127-132.

919 Walker, T.R. (1967) Formation of Red Beds in Modern and Ancient Deserts.

920 Geological Society of America Bulletin, 78, 353-368.

921 Weaver, C.E. (1958) A discussion on the origin of clay minerals in sedimentary rocks.

922 Clays and clay minerals, 5, 159-173.

923 Weber, K.A., Achenbach, L.A. and Coates, J.D. (2006) Microorganisms pumping

924 iron: anaerobic microbial iron oxidation and reduction. Nature Reviews Microbiology,

$925752-764$.

926 Worden, R.H. and Morad, S. (2003) Clay minerals in sandstones: controls on

927 formation, distribution, and evolution. In: Clay Mineral Cements in Sandstones (Eds

928 R.H. Worden and S. Morad). Blackwell Publishing, Oxford, UK.

929

930

\section{List of figures}

931 Figure 1 - Montage of representative reduction spheroids observed within the

932 Tumblagooda Sandstone. A and B are reduction spheroids observed within the

933 sandstone of the Facies Association 3 with relatively small, zoned, and less mineralised

934 cores. C and D are reduction spheroids with larger, darker, and more densely

935 mineralised cores observed in siltstones within Facies Association 4.

936 Figure 2 - Map of the tectonic units along the Western Australian margin, modified

937 from Mory and Hocking (2008).

938 Figure 3 - A. Map of the regional geology and extent of the Tumblagooda Sandstone

939 around the Kalbarri townsite, modified from Martin et al. (2016). Note here, the letters

940 next to formation names indicate formation ages and the black box surrounding the

941 Kalbarri townsite represents the area in Figure 3b. Map (B) and satellite photograph (C)

942 of the coastal exposures of the Tumblagooda Sandstone studied.

943 Figure 4 - Stratigraphic log of FA1-4 of the Tumblagooda Sandstone at Red Bluff. Beds

944 known to host reduction spheroids are indicated. Modified from Trewin and McNamara 
945 (1995). Note here that the thickness of the Gabba Gabba Member is intentionally exaggerated so as to ensure it is visible within the section due to its importance as a marker bed. Additionally, the abbreviations RVU and RBU are acronyms for Rainbow Valley unit and Red Bluff unit and are discussed on page 10.

949 Figure 5 - X-ray computed tomography scan of two whole reduction spheroids,

950 displaying their three-dimensional nature and a spheroidal core composed of higher

951 density minerals. The scanned material is coloured red, green, blue, and grey in order of

952 decreasing density. Sampled from the Red Bluff Unit (FA3).

953 Figure 6 - SEM photomicrographs of mineral phases within the Tumblagooda

954 Sandstone reduction spheroids. A. Backscattered electron (BSE) image of dense

955 interstitial microplaty haematite $(\mathrm{MplH})$ that occurs throughout the reduction spheroid

956 cores between grains of quartz $(\mathrm{Qz})$ and microcline $(\mathrm{Mc})$. B. Secondary electron (SE)

957 image of the microplaty haematite that occurs within the reduction spheroid cores. C.

958 BSE image of microplaty haematite occurring in proximity to intergrown fine haematite 959 (haem) and the illite (Ilt) matrix that is common outside of the reduction spheroid cores.

960 D. BSE image of mixed fine haematite and illite that is common throughout red portions

961 of reduction spheroid cores. E. BSE image of a cluster of acicular authigenic anatase

962 (Ant). F. BSE image of a grain with titaniferous laths arranged in a trellis-like

963 orientation. G. BSE image of relatively coarse blocky authigenic anatase occurring

964 within a reduction spheroid core, proximal to microplaty haematite. H. BSE image of

965 two distinct morphologies of authigenic anatase occurring in proximity to one another.

966 One type is very fine and granular whilst the other is relatively coarse and typically

967 blocky. 
968 Figure 7 - A. BSE image of a grain of authigenic anatase with inclusions of uraninite

969 (Urn). B. Typical BSE image of a portion of the pale reduced zone within a given

970 reduction spheroid; interstitial areas are dominated by an illite matrix with dispersed

971 svanbergite. C. BSE image of a cluster of fine authigenic svanbergite grains occurring

972 in a void within a quartz grain. D. BSE image of a cubic grain of svanbergite (Sva)

973 zoned with an outer gorceixite (Gor) rim, the dashed line indicates the boundary

974 between these two compositions. E. BSE image of fine authigenic monazite (Mnz) that

975 occurs within some reduction spheroids around the edges of quartz grains. In this case,

976 they occur in line with voids in an overgrown quartz grain that may be a product

977 monazite that grew around the edge and has since been removed. F. BSE image of a

978 typical unaltered detrital ilmenite grain that occurs within the host Tumblagooda

979 Sandstone but not in the reduction spheroids, note the primary magmatic exsolution

980 textures between Fe and Ti-rich portions.

981 Figure 8 - A. Mosaic of RBU-RS-50. B. XRF map of a RBU-RS-50; a reduction

982 spheroid core retrieved from the RBU of the Tumblagooda Sandstone showing

983 distribution of $\mathrm{Si}, \mathrm{K}, \mathrm{Fe}$, and $\mathrm{Ti}$. Here it is clear that haematite $(\mathrm{Fe})$ occurs as an

984 interstitial component between detrital quartz (Si) and K-feldspar (K), with Ti-bearing

985 phases occurring along the prevailing sedimentary fabric. C. Mosaic of RVU-RS-55. D.

986 XRF map of a RVU-RS-55; a reduction spheroid core retrieved from the RBU of the

987 Tumblagooda Sandstone displaying Si, K, Fe, and Ti. E. XRF map of RVU-RS-55;

988 displaying Fe diffusion along sedimentary fabric away from Fe-rich core.

989 Figure 9 - Paragenetic sequence of the formation of the Tumblagooda Sandstone

990 reduction spheroids from petrographic analysis. Here the genesis of these reduction

991 spheroids is broken into three stages. Stage one: the initial formation of the reduction 
992 spheroids and active bacterial metal reduction. Stage two: the cessation of active

993 bacterial metal reduction and the subsequent oxidation and heating of the reduction

994 spheroids during burial. Stage three: the exhumation of the reduction spheroids within

995 the wider Tumblagooda Sandstone and their exposure to concomitantly lower

996 temperatures. Note here that the change in colour from blue in stage one to red in stage

997 two is indicative of the progressive heating of the reduction spheroids during burial. 

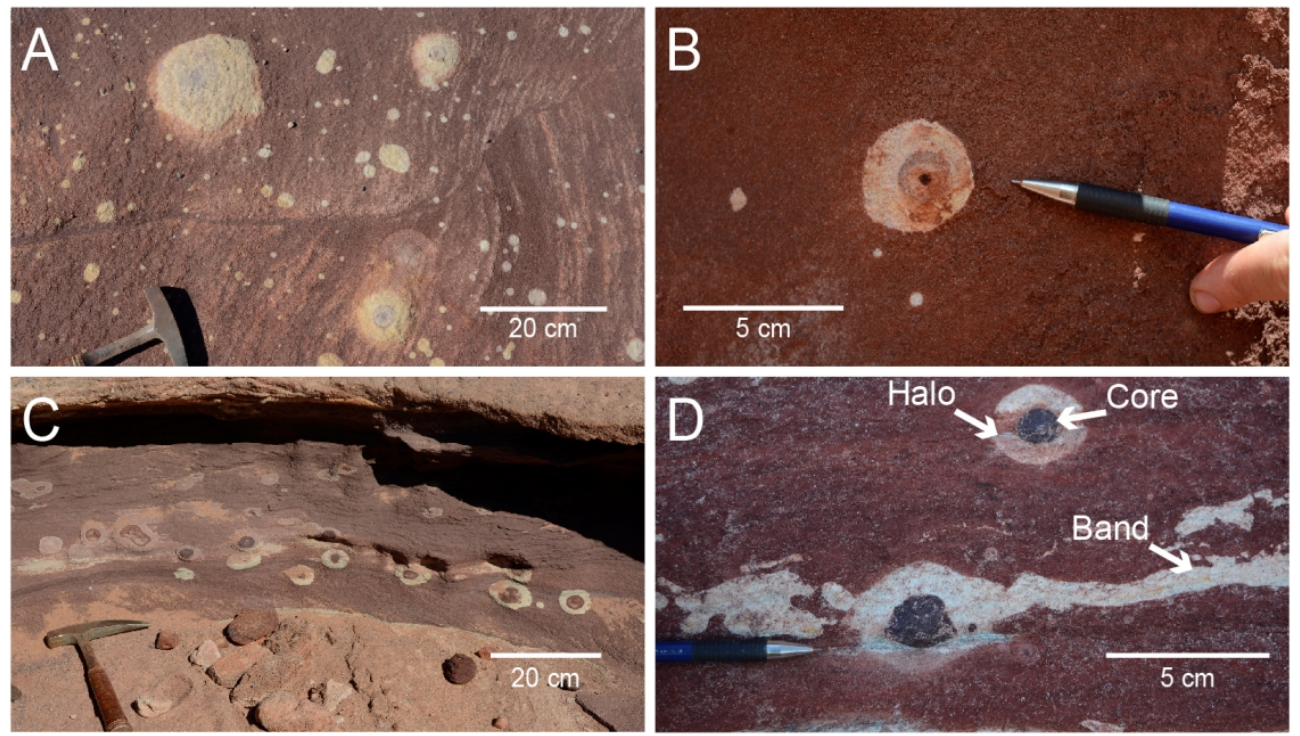

C:\Users $\backslash 17089313 \backslash$ OneDrive - Curtin University of Technology Australia\PhD\Papers\Tumblagooda RS Summary \Part One \Review\Figures\PNG

$140 \times 79 \mathrm{~mm}(300 \times 300 \mathrm{DPI})$ 


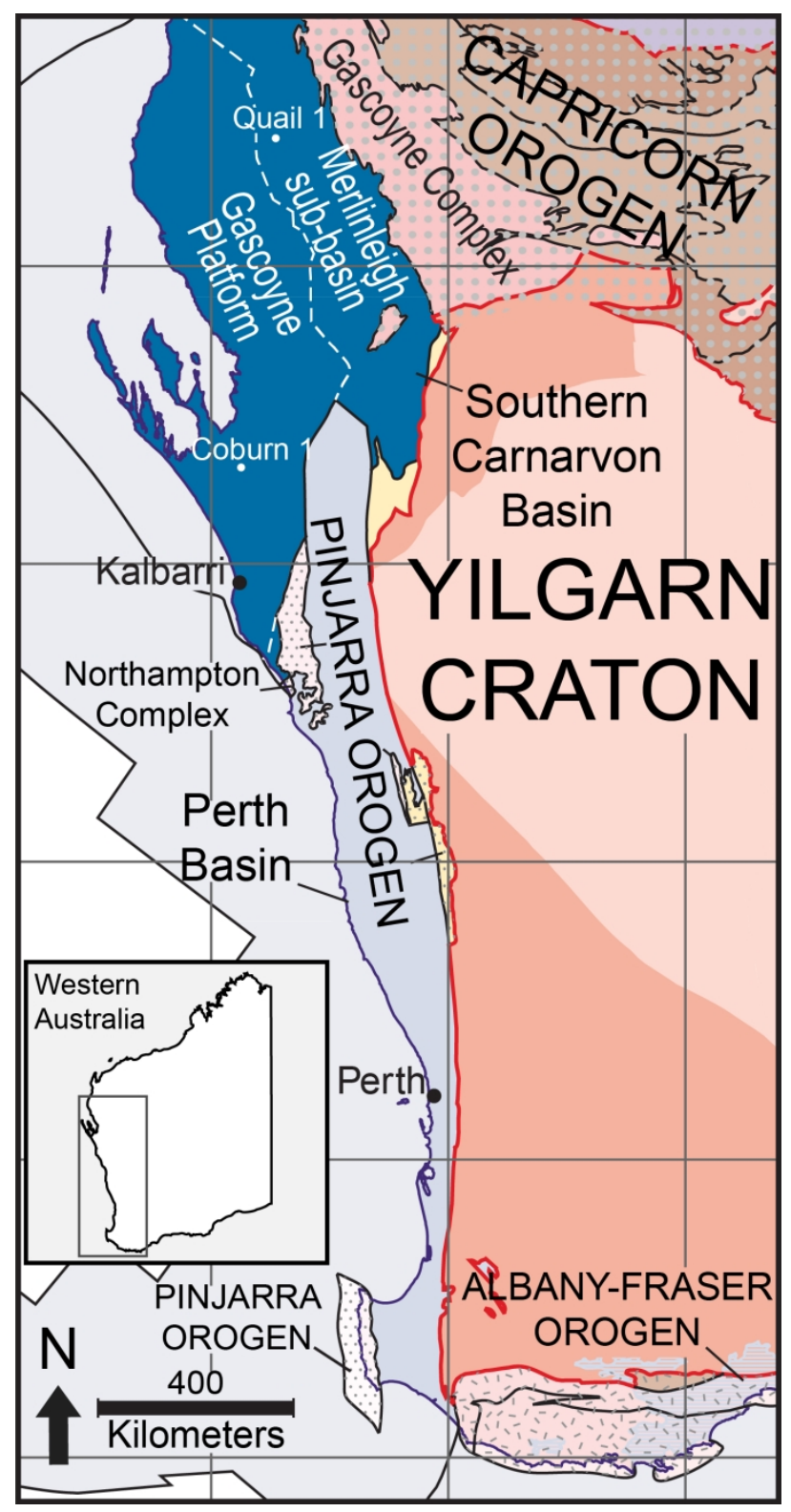

Figure 2 - Map of the tectonic units along the Western Australian margin, modified from Mory and Hocking (2008). 

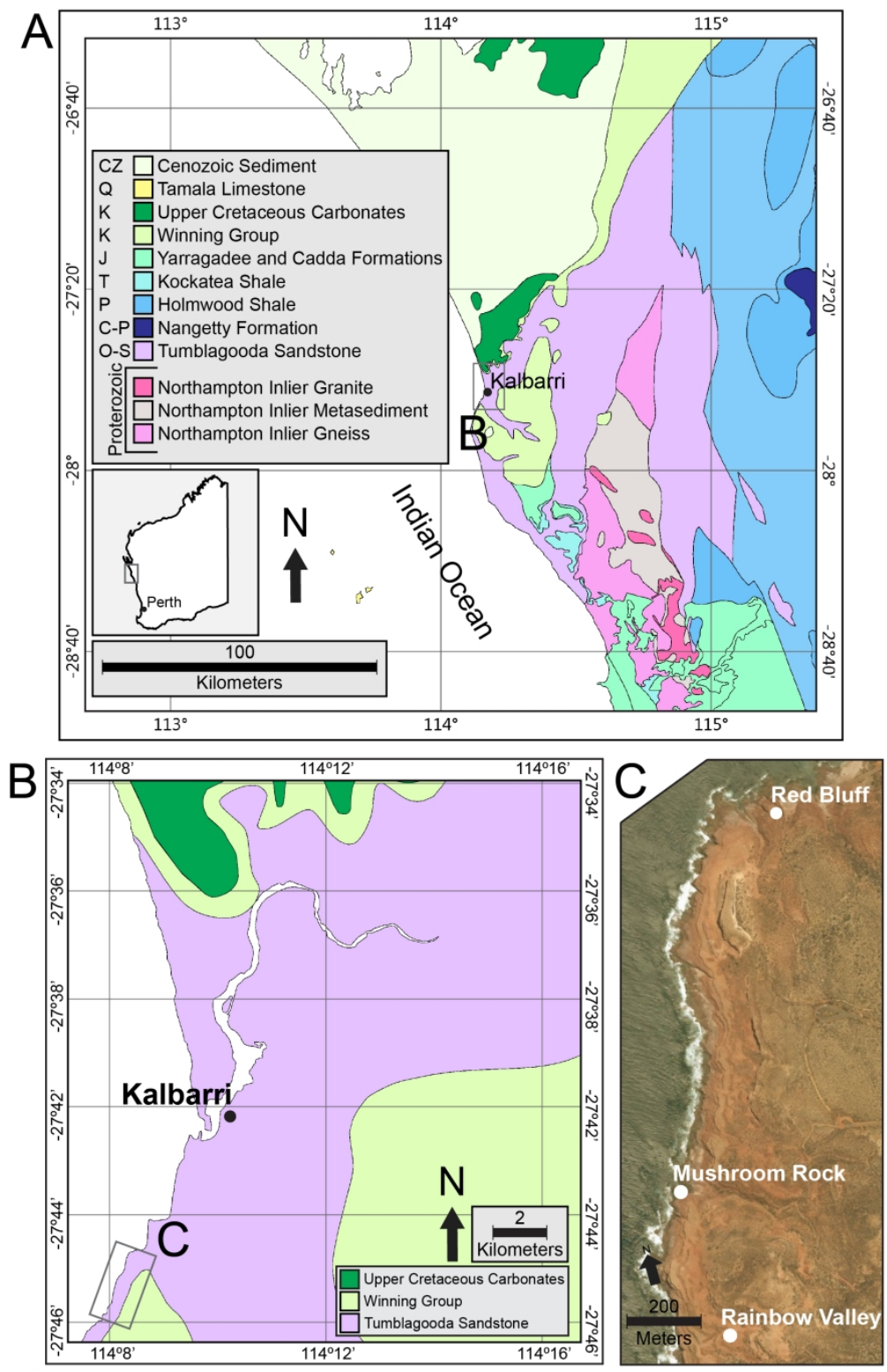

Figure 3 - A. Map of the regional geology and extent of the Tumblagooda Sandstone around the Kalbarri townsite, modified from Martin et al. (2016). Note here, the letters next to formation names indicate formation ages and the black box surrounding the Kalbarri townsite represents the area in Figure $2 \mathrm{~b}$. Map (B) and satellite photograph (C) of the coastal exposures of the Tumblagooda Sandstone studied. 


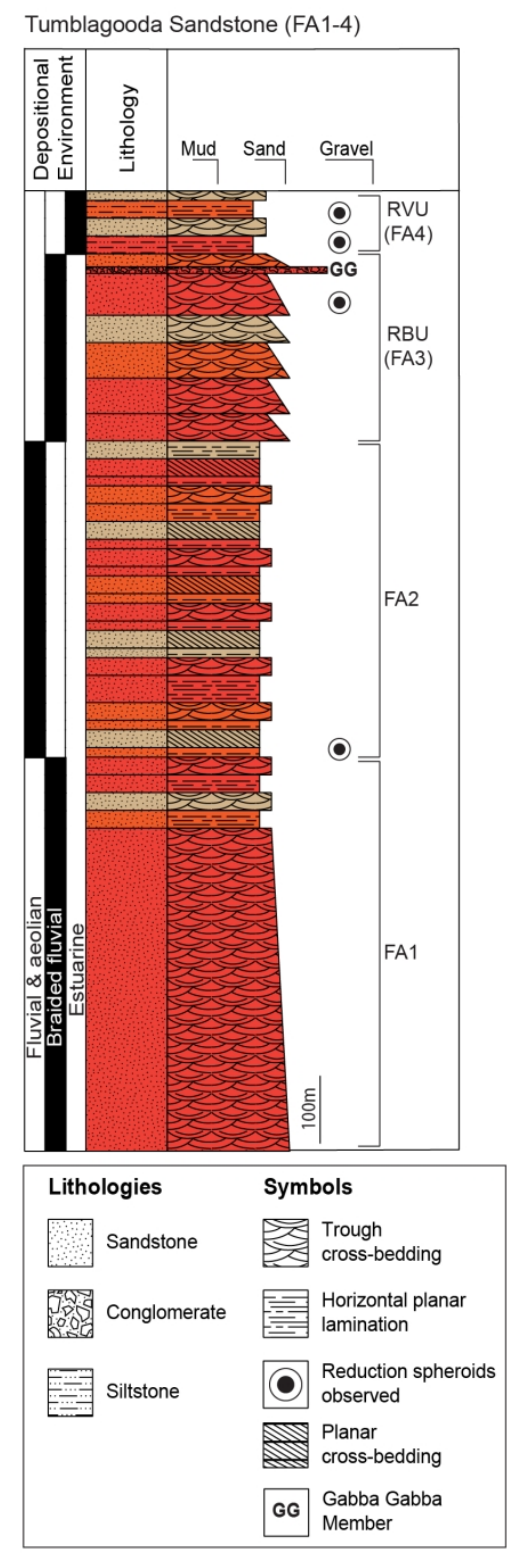

Figure 4 - Stratigraphic log of FA1-4 of the Tumblagooda Sandstone at Red Bluff. Beds known to host reduction spheroids are indicated. Modified from Trewin and McNamara (1995). Note here that the thickness of the Gabba Gabba Member is intentionally exaggerated so as to ensure it is visible within the section due to its importance as a marker bed. Additionally, the abbreviations RVU and RBU are acronyms for Rainbow Valley unit and Red Bluff unit and are discussed on page 10. 

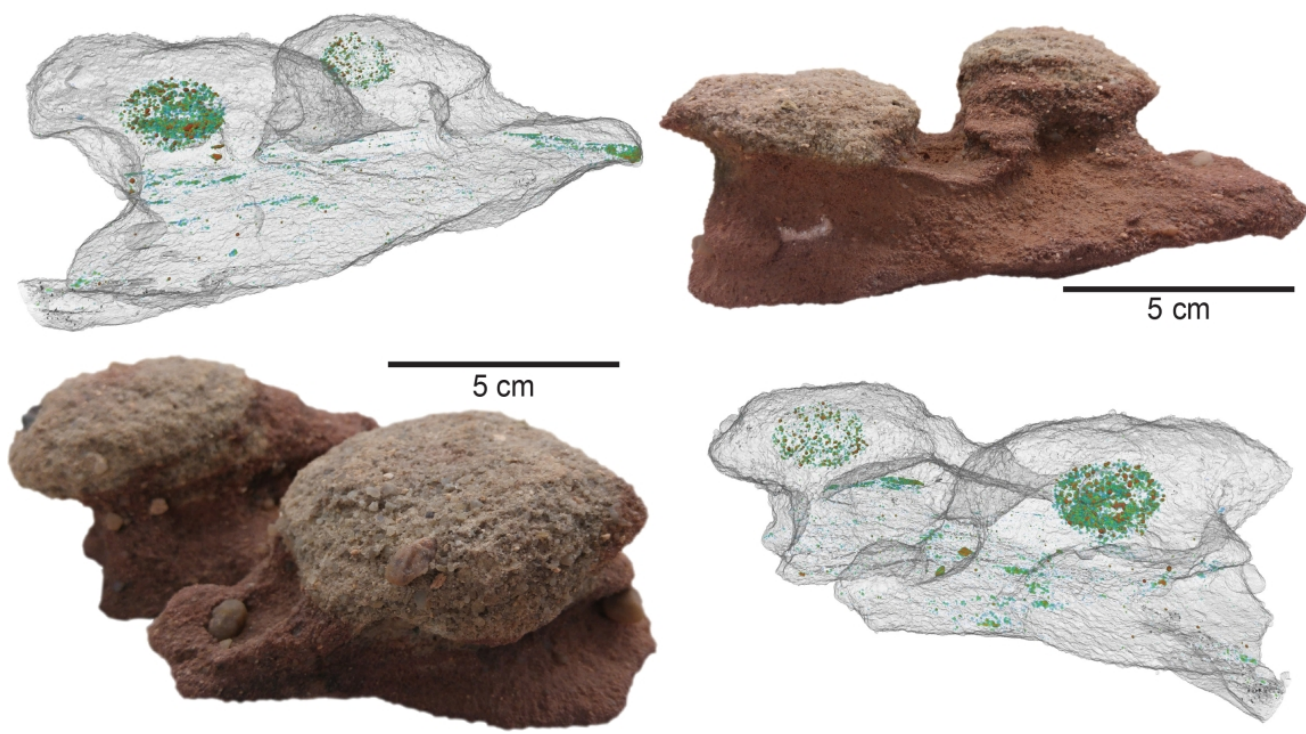

Figure 5 - X-ray computed tomography scan of two whole reduction spheroids, displaying their threedimensional nature and a spheroidal core composed of higher density minerals. The scanned material is coloured red, green, blue, and grey in order of decreasing density. Sampled from the Red Bluff Unit (FA3). 


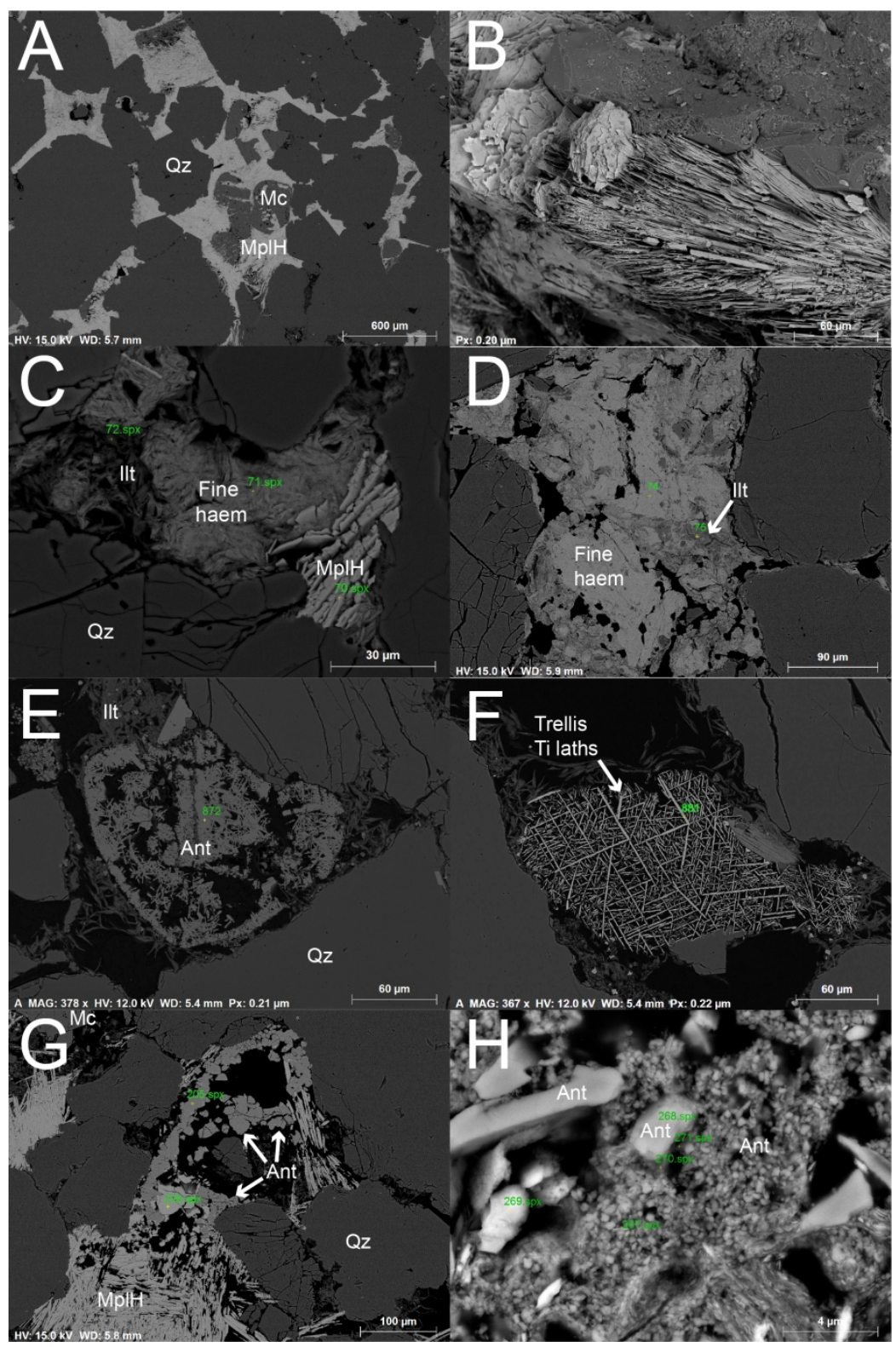

Figure 6 - SEM photomicrographs of mineral phases within the Tumblagooda Sandstone reduction spheroids. A. Backscattered electron (BSE) image of dense interstitial microplaty haematite (MplH) that occurs throughout the reduction spheroid cores between grains of quartz $(\mathrm{Qz})$ and microcline (Mc). $\mathrm{B}$. Secondary electron (SE) image of the microplaty haematite that occurs within the reduction spheroid cores. C. BSE image of microplaty haematite occurring in proximity to intergrown fine haematite (haem) and the illite (Ilt) matrix that is common outside of the reduction spheroid cores. D. BSE image of mixed fine haematite and illite that is common throughout red portions of reduction spheroid cores. E. BSE image of a cluster of acicular authigenic anatase (Ant). F. BSE image of a grain with titaniferous laths arranged in a trellis-like orientation. G. BSE image of relatively coarse blocky authigenic anatase occurring within a reduction spheroid core, proximal to microplaty haematite. $\mathrm{H}$. BSE image of two distinct morphologies of authigenic anatase occurring in proximity to one another. One type is very fine and granular whilst the other is relatively coarse and typically blocky. 


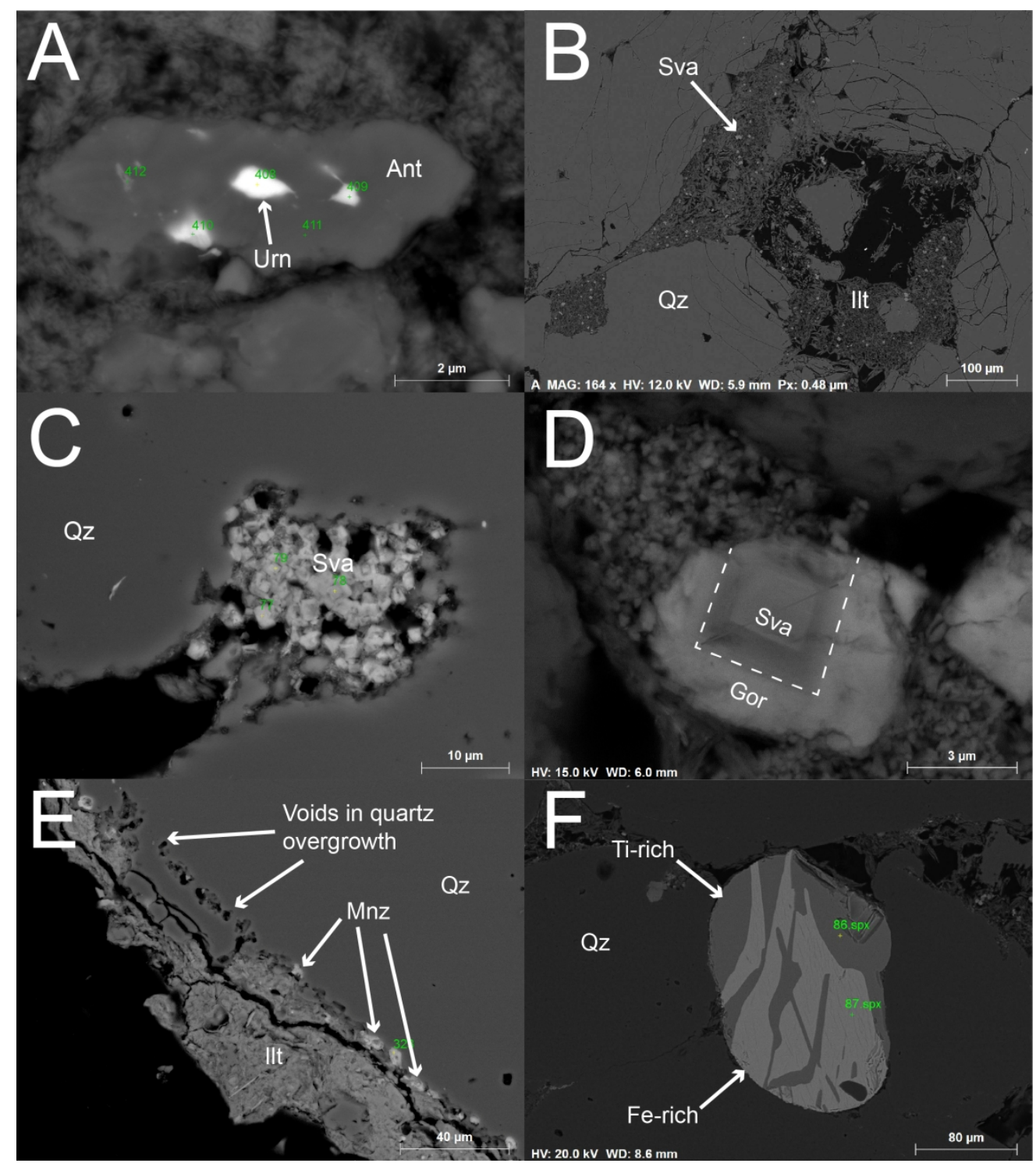

Figure 7 - A. BSE image of a grain of authigenic anatase with inclusions of uraninite (Urn). B. Typical BSE image of a portion of the pale reduced zone within a given reduction spheroid; interstitial areas are dominated by an illite matrix with dispersed svanbergite. C. BSE image of a cluster of fine authigenic svanbergite grains occurring in a void within a quartz grain. D. BSE image of a cubic grain of svanbergite (Sva) zoned with an outer gorceixite (Gor) rim, the dashed line indicates the boundary between these two compositions. E. BSE image of fine authigenic monazite ( $\mathrm{Mnz}$ ) that occurs within some reduction spheroids around the edges of quartz grains. In this case, they occur in line with voids in an overgrown quartz grain that may be a product monazite that grew around the edge and has since been removed. F. BSE image of a typical unaltered detrital ilmenite grain that occurs within the host Tumblagooda Sandstone but not in the reduction spheroids, note the primary magmatic exsolution textures between Fe and Ti-rich portions. 

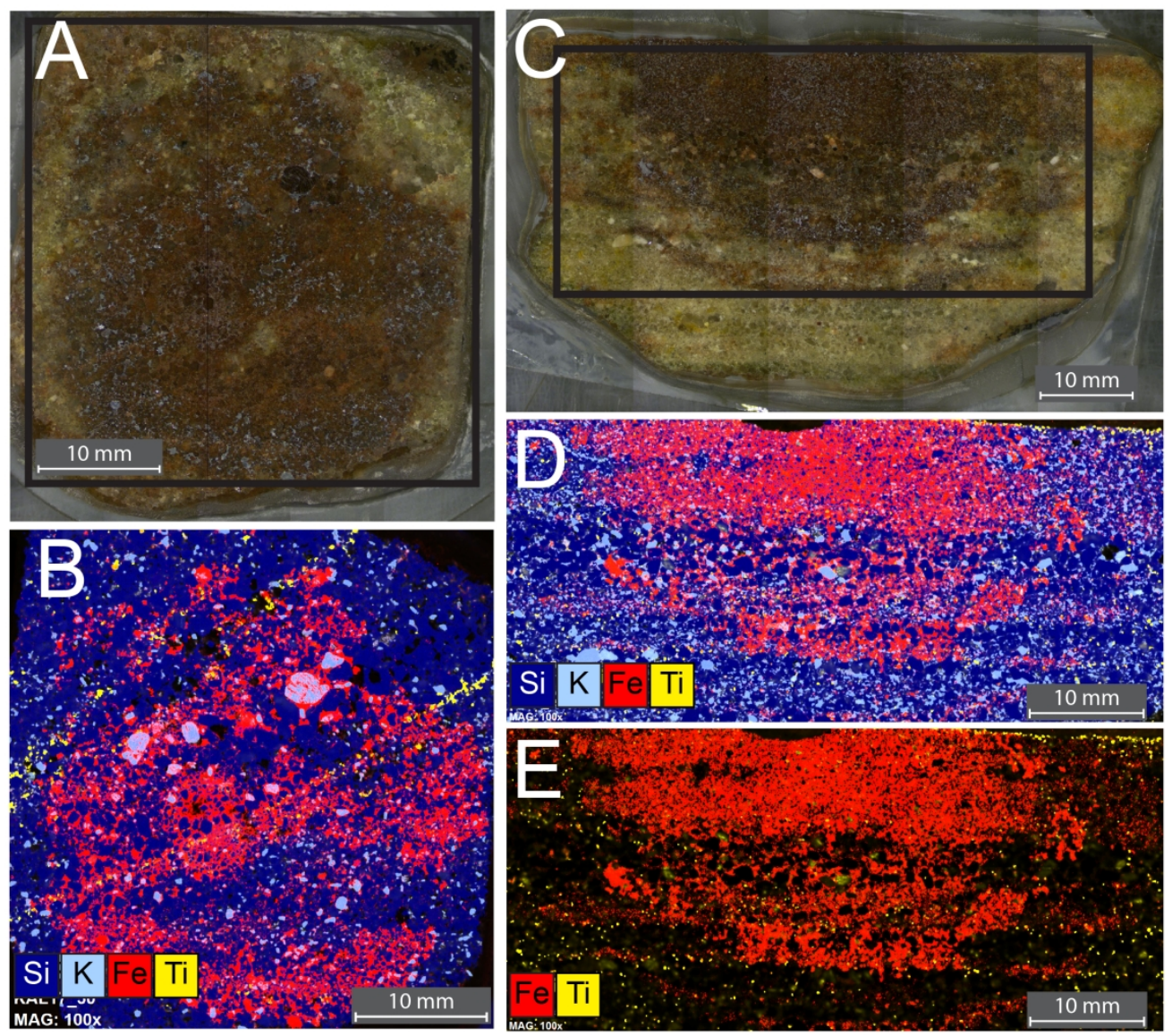

Figure 8 - A. Mosaic of RBU-RS-50. B. XRF map of a RBU-RS-50; a reduction spheroid core retrieved from the RBU of the Tumblagooda Sandstone showing distribution of $\mathrm{Si}, \mathrm{K}, \mathrm{Fe}$, and Ti. Here it is clear that haematite $(\mathrm{Fe})$ occurs as an interstitial component between detrital quartz ( $\mathrm{Si}$ ) and $\mathrm{K}$-feldspar $(\mathrm{K})$, with Tibearing phases occurring along the prevailing sedimentary fabric. C. Mosaic of RVU-RS-55. D. XRF map of a RVU-RS-55; a reduction spheroid core retrieved from the RBU of the Tumblagooda Sandstone displaying Si, $\mathrm{K}, \mathrm{Fe}$, and Ti. E. XRF map of RVU-RS-55; displaying Fe diffusion along sedimentary fabric away from Fe-rich core. 


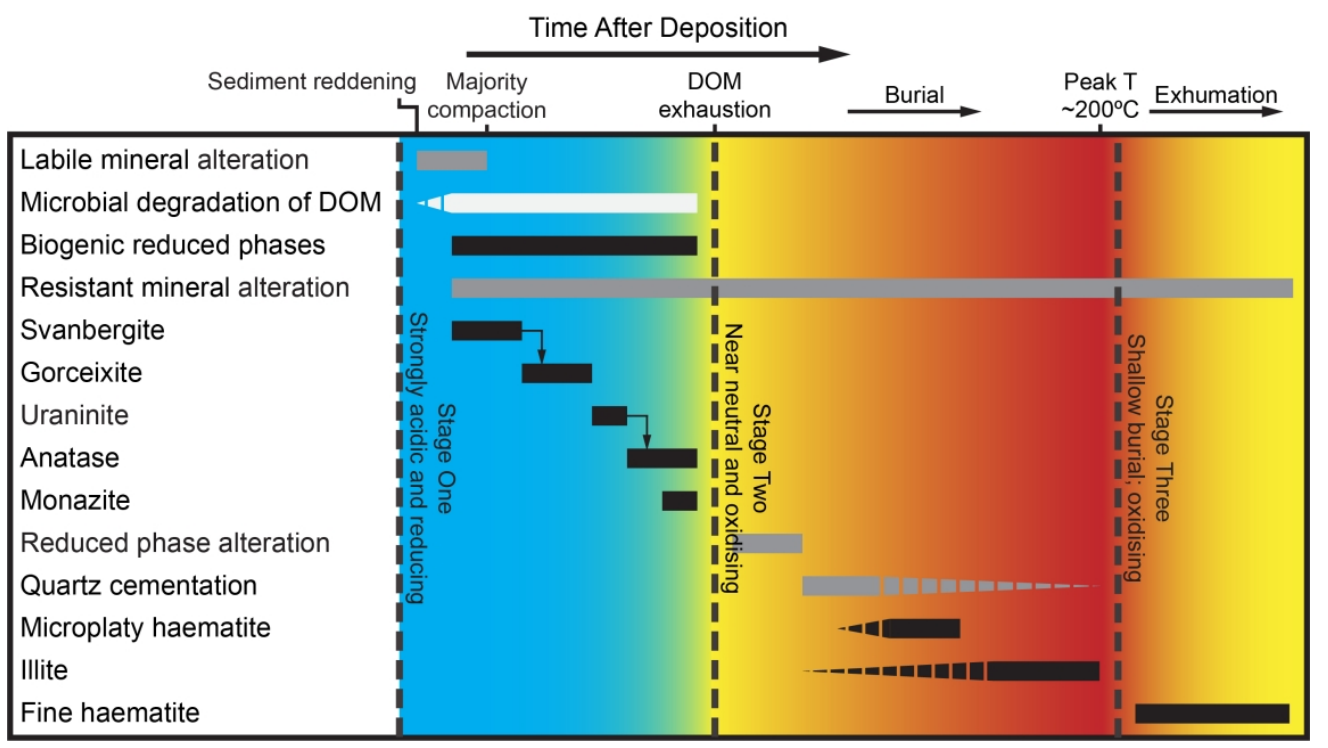

Figure 9 - Paragenetic sequence of the formation of the Tumblagooda Sandstone reduction spheroids from petrographic analysis. Here the genesis of these reduction spheroids is broken into three stages. Stage one: the initial formation of the reduction spheroids and active bacterial metal reduction. Stage two: the cessation of active bacterial metal reduction and the subsequent oxidation and heating of the reduction spheroids during burial. Stage three: the exhumation of the reduction spheroids within the wider Tumblagooda Sandstone and their exposure to concomitantly lower temperatures. Note here that the change in colour from blue in stage one to red in stage two is indicative of the progressive heating of the reduction spheroids during burial. 
Table 1 - Summary of minerals with abundance and nature of occurrence in host Tumblagooda Sandstone and reduction spheroids.

\begin{tabular}{|c|c|}
\hline Mineral phase & Abundance and nature of occurrence \\
\hline Quartz & $\begin{array}{l}\text { Common. Primary. Dominant detrital mineral in } \\
\text { host rock and throughout reduction spheroids. }\end{array}$ \\
\hline K-feldspar & $\begin{array}{l}\text { Common. Primary. Abundant detrital mineral in } \\
\text { host rock and throughout reduction spheroids. }\end{array}$ \\
\hline Heavy minerals & $\begin{array}{l}\text { Common. Primary. Detrital zircon, monazite, } \\
\text { ilmenite, and rutile common in red host } \\
\text { sandstone. Detrital ilmenite, rutile, and monazite } \\
\text { are rare in white sandstone and reduction } \\
\text { spheroids. }\end{array}$ \\
\hline Svanbergite & $\begin{array}{l}\text { Common. Authigenic. Occurs throughout } \\
\text { reduction spheroids in aggregates of cubic } \\
\text { crystals filling interstitial space. }\end{array}$ \\
\hline Gorceixite & $\begin{array}{l}\text { Common. Authigenic. Occurs exclusively } \\
\text { rimming svanbergite crystals. }\end{array}$ \\
\hline Uraninite & $\begin{array}{l}\text { Trace. Authigenic. Occurs exclusively as } \\
\text { inclusions within anatase throughout spheroids. }\end{array}$ \\
\hline Anatase & $\begin{array}{l}\text { Trace. Authigenic. Occurs as clusters of acicular } \\
\text { anatase needles in interstitial space in reduction } \\
\text { spheroid cores with very fine }(<1 \mu \mathrm{m}) \\
\text { surrounding aggregates. }\end{array}$ \\
\hline Monazite & $\begin{array}{l}\text { Trace. Authigenic. Occurs as clusters of crystals } \\
(<10 \mu \mathrm{m}) \text { commonly adhered to detrital quartz } \\
\text { grains in reduction spheroid cores. }\end{array}$ \\
\hline $\begin{array}{l}\text { Microplaty haematite } \\
\text { (MplH) }\end{array}$ & $\begin{array}{l}\text { Common. Authigenic. Dominates interstitial } \\
\text { space through majority of reduction spheroid } \\
\text { cores. }\end{array}$ \\
\hline Illite & $\begin{array}{l}\text { Common. Authigenic. Dominates interstitial } \\
\text { space in reduction spheroid halos and host rock, } \\
\text { also occurs through less dense reddish cores. }\end{array}$ \\
\hline Fine haematite & $\begin{array}{l}\text { Common, occurs in association with } \mathrm{MplH} \text { in } \\
\text { reddish cores and commonly intergrown with } \\
\text { illite. }\end{array}$ \\
\hline
\end{tabular}

Summary of minerals with abundance and nature of occurrence in host Tumblagooda Sandstone and reduction spheroids 